HID 46 (2019)

\title{
LOS OFICIOS DEL ARMAMENTO EN CÓRDOBA EN EL SIGLO XV $(1460-1510)^{1}$
}

\author{
THE ARMAMENT TRADES IN CORDOBA IN THE \\ $15^{\mathrm{TH}}$ CENTURY (1460-1510)
}

\author{
Josefa Leva Cuevas \\ Universidad de Córdoba \\ pepilc52@ptvtelecom.com ORCID: https://orcid.org/0000-0003-0142-9426
}

RESUMEN: Análisis de los oficios del armamento, en sus diversas especialidades: armeros, espaderos, asteros, ballesteros, cuchilleros, adargueros y vaineros. Especialmente los armeros, con la petición de Ordenanzas en 1512, por el armero cordobés Martín de Aragón. Economía, relaciones familiares, comerciales y solidaridad de los oficios, que muestran la vida cotidiana de estos profesionales en la Córdoba de finales del siglo XV, en relación con una sociedad en conflicto continuo.

PALABRAS CLAVE: violencia; armas; armadura; espada; lanza; rentabilidad; guerra.

ABSTRACT: Analysis of weapons trades, in its various specialties: armourers, swordsmiths, asteros, crossbow artisans, cutlers, shields and vain artisans. Especially the armourers, with the request for Ordinances in 1512, by the cordoban armourer Martín de Aragón. Economy, family relations, dealings and solidarity of the trades, that show everyday life of these professionals in the Cordoba of the end of the $15^{\text {th }}$ century, in relation to a society in continuous conflict.

KEYWORDS: violence; arms; armor; sword; spear; profitability; war.

Recibido: 5-3-2019; Aceptado: 30-5-2019; Versión definitiva: 18-6-2019.

1. Abreviaturas utilizadas: AGS, RGS $=$ Archivo General de Simancas, Registro General del Sello; AHPCO, PN = Archivo Histórico Provincial de Córdoba, Protocolos Notariales; AMCO = Archivo Municipal de Córdoba.

Copyright: (C) Editorial Universidad de Sevilla. Este es un artículo de acceso abierto distribuido bajo los términos de la licencia de uso y distribución Creative Commons Reconocimiento-No-ComercialSinObraDerivada 4.0 (CC BY-NC-ND 4.0) 


\section{LOS OFICIOS DEL ARMAMENTO}

Para el análisis de esta industria en el siglo XV se han utilizado los Protocolos Notariales del Archivo Histórico Provincial de Córdoba y el Padrón cordobés de $1509^{2}$, de las seis collaciones que se han conservado: San Andrés, San Nicolás de la Villa, la Magdalena, San Pedro, San Nicolás de la Axerquía y San Miguel. De todo ello se ha podido conocer a las dos collaciones que agruparon mayoritariamente los oficios reseñados en la ciudad de Córdoba, las de San Nicolás de la Axerquía y San Pedro, lo que se ha visto favorecido por el hecho de que se conserven las dos en el citado padrón.

Todos los elementos de la protección del cuerpo, las corazas y mallas, cascos y escudos, junto con el armamento propiamente dicho, la espada, lanza, ballesta, puñales y dagas, etc., y los ornamentos del arnés, necesitaban de un número importante de artesanos y de muchos gastos. En este sentido lo expone Fossier cuando refiere que en el siglo XII se estimaba que un caballero solo podía estar correctamente equipado si poseía o explotaba 150 hectáreas, en el siglo XIV le hará falta tres veces más ${ }^{3}$.

En Córdoba, la suma de los profesionales dedicados, tanto a la protección o armaduras como a las diversas armas, incluidos los cuchilleros, supone un porcentaje dentro de la rama del metal del orden del 30,2\%, es decir, casi un tercio de los profesionales de dicha rama se dedicaron a la industria armamentística.

A sus talleres acudía una clientela variada, aunque mayormente eran la nobleza y la oligarquía urbana las que demandaban más sus servicios, y en los mismos cuelgan las armas del guerrero, las nuevas y aquellas que van a reparar, a enderezar, o soldar nuevamente y a bruñir o a limpiar, como los armeros a los que se refiere Fossier cuando dice que teje las cotas de malla, remacha un casco, refunde y templa las hojas de las espadas.

Las armaduras eran verdaderas obras de ingeniería, hechas con la finalidad de desviar los golpes de las armas utilizadas por el adversario y permitir al usuario salvar la vida, así como la mayor movilidad posible para su defensa. Las armaduras de placas o arnés blanco podían llegar a pesar unos $35 \mathrm{~kg}$. Los artesanos armeros, pues, debían ser a la vez ingenieros y artistas, ya que las armaduras y las armas tenían que ser fuertes, ligeras y apuestas. Así su eficacia en la guerra o lucha y en la estética, donde la presencia y gallardía tenían un papel en la imagen disuasoria ante el contrario, a la vez que ante la sociedad en general, es decir, la ostentación como un fundamento importante del mismo poder. Baste decir que para la caballería siempre hubo excepciones en las prohibiciones desarrolladas por las leyes suntuarias. Por ejemplo, en referencia al uso de la seda que se desarrolló en la pragmática de 1499, dada por los Reyes Católicos, se hizo la excepción amplia a todas aquellas personas que tuviesen y mantuviesen caballo continuamente, y es

2. AMCO, Caja 1085, R. 203.

3. Fossier 2002, p. 176.

4. Ibid. p. 159. 
más, los caballeros, en las bridas y sillas de montar podían llevar guarniciones de seda y también seda en las corazas, faldas, gocetes, capacetes, baberas y quijotes, relativos a piezas de las armaduras, o llevar un cojín de seda en las sillas de jineta, mientras la seda tenía múltiples limitaciones para el resto ${ }^{5}$. En esta sociedad bajomedieval se llegó, incluso a utilizar el consumo de ciertos productos suntuarios con fines políticos, sirviendo de contrapartida a algunas exigencias, como en el caso de sostenimiento de caballo y armas o equipo militar ${ }^{6}$, lo cual beneficiaría también a los artesanos encargados de tales industrias, tanto por la demanda como por la calidad exigida.

En la industria del armamento hay una clara distinción entre los elementos de protección y los de lucha y agresión, que bien distinguían las Partidas, al separar los términos arma y armadura: arma como todo lo que es para ferir, ha nome armas, y armadura todo aquello que visten los omes, o ponen sobre sí para defender sus cuerpos, en dicha armadura ${ }^{7}$. Continúan las Partidas incidiendo sobre las armaduras y la defensa que suponían para el que las llevaba: ... e que sepan ellos fazer armadura, contra aquellas, con que se defiendan, porque no reciban ligeramente muerte, ni daño dellos. Mientras las armas: otrosí las armas que ellos traxeren, que la fagan de la guisa que entendieren, que mayor daño podrán fazer con ellas, a aquellos con quien guerrean ${ }^{8}$. La distinción es clara entre protección para no ser herido o muerto, y la de herir con el mayor daño y eficacia posibles.

Pasamos al análisis de cada oficio dedicado a esta industria, con las fuentes mencionadas, detallando en primer lugar los oficios en sus labores y ordenanzas constitutivas.

\section{SOBRE LOS OFICIOS Y ORDENANZAS}

Los armeros eran los encargados, junto con coraceros, malleros y fabricantes de bastida, de hacer, deshacer y limpiar, las piezas de protección así como las armas que utilizaban los caballeros cordobeses, según unas ordenanzas de 1512 solicitadas por el armero Martín de Aragón, residente en la calle Armas de la collación de San Nicolás de la Axerquía, al cabildo municipal el día 5 de abril de dicho año9 . En esta solicitud exponía dicho armero: Que se otorgaran ordenanzas para una profesión como la de armero basada en un oficio de calidad e importante para defender y amparar las vidas de los hombres y ya que en otros oficios de menor calidad las había para saber como regirse y hacer justicia, pues en el de la armería también debía de haberlas por el bien de la ciudad y del regimiento. Se redactaron regulando que los oficiales supieran hacer, deshacer y limpiar las armaduras, mallas, coseletes, corazas, espadas y otras armas, así como los materiales

5. González Arce 1998, pp. 159-160.

6. Ibid. p. 231.

7. Las Partidas, segunda Partida, en Martínez Martínez 1988, p. 107.

8. Segunda Partida. Ibid., pp. 107-108.

9. AMCO, Caja 16, doc. 1 . 
a usar en cada caso, y evitar falsedades y errores en la confección de las mismas, tanto por la ineficiencia como por el interés económico en conseguir mayores beneficios, engañando a la posible clientela, especialmente a aquellos que desconocen la materia, y todo ello precisaba de veedores y facultativos que vigilaran el oficio. Precisamente en uno de los apartados se señala que hay muchas maldades y traiciones en el oficio, refiriéndose concretamente al caso de las mallas, que pueden los oficiales vender mallas de hierro por de acero, y muchas piezas de malla adobarlas y hacerlas con malla de latón y plata malla, que es malla abierta que no tiene piezas ninguna y es muy gran falta para el que lleva, que no tiene defensa ninguna.

Por tanto cualquier corrupción, mal hacer y fraude en estos productos suponía la indefensión del guerrero y su posible muerte en el combate, de ahí la importancia de tal regulación que dejaba ver, por otro lado, el incumplimiento de las buenas labores del oficio, aunque no siempre las ordenanzas pudieron evitar.

Por todo lo expuesto es por lo que el citado armero lo solicitó al ayuntamiento. En otros apartados sigue con la exposición: que ninguna cota se pueda vender sin que tenga un sello de latón clavado en el que se diga la suerte si es de hierro o de acero, y si la cota llevase el pecho de una suerte, la espalda de otra y las mangas de otra, que cada parte de las tres tenga su sello con indicación de si es de acero o hierro, incluso, si alguien quiere vender alguna cota y la lleva a casa del oficial para que se la venda, antes de hacerlo ha de echarle el sello mencionado. El control era severo. Y aún se cuidaban de no deshacer armas, corazas o mallas, pues se habían desecho muchas y se deshacen cada día otras muchas por quienes no sabían hacerlo, como caldereros, herreros, etc., y convenía poner diligencia para que no sucediera, puesto que, aunque estuviesen mohosas, se podían guarnecer y aprovechar. O que los espaderos no osaran tomar mallas para limpiar, porque desconocían el tiempo necesario en que debían estar echadas en vinagre, pudiéndose echar a perder y después el oficial disimular ante el desconocimiento del dueño de dónde procedía el mal.

Terminan las ordenanzas con la relación de los oficiales que había en el momento de su aprobación:

- Luís Gutiérrez, coracero. Entiende en hacer corazas.

- En las Tendillas de Calatrava hay un oficial que labra malla y no otra cosa.

- Pedro Fernández de Alcántara. Entiende en mallas y en armas.

- Pedro Gómez, en corazas, mallas, armas y bastida.

- Martín de Aragón, en corazas, armas, mallas y bastida.

Todo ello, firmado por Martín de Aragón.

El tipo de armadura usado por los caballeros era el llamado arnés o coselete con gola (armadura ligera compuesta de gola, que cubría cuerpo y garganta y que se componía también de peto, espaldar, escarcelas, brazaletes y celada). El coselete también podía llevar escarcelón largo (elemento que cubría desde la cintura al muslo y que debía ir sujeto con dos correas, una en medio y otra en la parte inferior), capacete o casco de hierro para defender la cabeza de golpes y cuchilla- 
das. Las cotas de malla podían ser: jacerina media (de acero, muy fina), jacerina media bocamenuda y mediana, jacerina de lambrequine (este término define el adorno heráldico que en forma de hojas de acanto baja de la parte superior del casco y rodea al escudo) y jacerina de lo viejo bocamenuda y mediana que, como su nombre indica, está hecha de acero viejo. Las corazas debían ir guarnecidas con no menos de 1.000 clavos, y llevar las launas convenientes, como son: quince en los delanteros, que al unirse con el volante o faldar han de ser 16 y tres de faldillas, que son el total 19 launas, y si son corazas con peto, deben llevar 16 launas más el peto y en la espalda, 18 por lo menos. Estas corazas pueden ir guarnecidas en seda de terciopelo, raso y brocado y el cordobán del mismo color ${ }^{10}$.

El oficio de armero era muy especializado y en él podían intervenir otros profesionales de diferentes actividades, pues llevaban una serie de labores complementarias, donde participaban elementos textiles y del cuero, ya expresado anteriormente. Del bien hacer de este oficio dependía la vida de los contendientes en buena parte, porque era la protección del caballero en la guerra, en los torneos, en la esgrima, etc., por tanto, dicho oficio iba unido a un mundo guerrero y de la caballería, junto con otros profesionales que completaban los elementos de ataque y defensa como espaderos, asteros, malleros, adargueros, etc. Es esta la industria armamentística de la época en cuanto al equipamiento individual. En este período hay que tener presente que Córdoba fue lugar importante en la guerra de Granada, donde los Reyes Católicos y su séquito acamparon durante bastante tiempo para dirigir las operaciones, de aquí salían huestes para las distintas campañas, y éstas necesitaban de dichos elementos o de su reparación, lo que daba trabajo a los distintos profesionales y, en concreto, a los armeros. Se unía a todo ello el ejercicio de la esgrima o el arte de prepararse para la lucha, donde Córdoba tuvo una escuela

10. La evolución de la protección corporal del caballero: desde mediados del siglo XI usaba la cota de malla que era una buena protección ante los golpes de espada quedando amortiguados, ya que debajo de ella llevaba un jubón acolchado para evitar las heridas por roce, protegiendo esta cota al conjunto del cuerpo. Hacia la mitad del siglo XII se superpone a esta cota otra de armas que los hace reconocibles reforzando la solidaridad de grupo. En el siglo XIII la cota de malla se refuerza con partes rígidas de metal o de cuero hervido en pecho, brazos y espalda, es la llamada armadura de láminas que va a conducir hacia la armadura rígida, no desapareciendo la cota de malla que iba por debajo. Ya en el siglo XV surge el gran arnés blanco, armadura completa con partes rígidas articuladas, de mayor protección pero también de mayor peso. El casco evoluciona al mismo compás, al yelmo se añade un nasal y a fines del siglo XII una chapa facial que va sobre una cofia de malla. En el XIII se convierte en el yelmo cerrado que se va complicando al agregarle elementos de protección y adorno como la heráldica. Se hace tan pesado que a mediados del siglo XV se sustituye por el bacinete de visera móvil. Aunque el peso de las armaduras de finales de la Edad Media podía ser considerable, del orden de los 25-30 kilos, éste se repartía por todo el cuerpo, permitiendo el movimiento en caballeros fuertes y bien entrenados. Las armaduras de las justas o torneos alcanzaban mayor peso con más de 50 kilos, pero solo se usaban para estas ocasiones. En los siglos XVI y XVII las armaduras de guerra adquirieron mayor grosor en un intento vano de resistir los proyectiles de la artillería. Según Ada Bruhn de Hoffmeyer, la Edad Media es la Historia de la caballería pesada, donde las armas y la táctica de la caballería feudal dominaban los campos de batalla de casi toda Europa. A cada fracaso de esta caballería medieval se buscaba una protección más fuerte y más pesada, pero que impedía la movilidad tanto para el hombre como para el caballo. También hay que tener en cuenta que desde el siglo XV comienza a funcionar la artillería con bombardas, lombardas, falconetes, etc., y otras armas que usaban la pólvora. Los armeros, pues, debieron participar de estos cambios en el transcurso de dicho siglo. Bruhn de Hoffmeyer 1988, pp. 31-99. 
afamada y un gremio de esgrimidores con sus ordenanzas. Los Reyes Católicos otorgaron una Provisión en 1478 para regular el precio por los derechos de examen que podían cobrar los maestros esgrimidores, así como el pago de la media annata. Una plaza donde tenían lugar los exámenes para conseguir el título de maestro, y las exhibiciones y festejos a los que siempre precedían los juegos de esgrima, y que era de gran vitalidad para la ciudad: la plaza de la Corredera, en la collación de San Pedro, que sirvió de marco para obras literarias como la de Vélez de Guevara, El Diablo Cojuelo ${ }^{11}$. Así pues, otra fuente de trabajo para los armeros, espaderos, etc., que derivó de la importancia que en Córdoba tuvo la esgrima ${ }^{12}$.

Los armeros debían ser además innovadores pues las armaduras fueron evolucionando a medida que se producían fallos o por las posibles mejoras que se podían introducir para algo tan vital como era la vida de los luchadores y contendientes. Así, sus talleres, en continua actividad, se convertían en centros de ensayo e innovación, en aras a encontrar mejoras en materiales y formas de protección. Puesto que las guerras, batallas y conflictos nunca se paraban y los intereses eran muchos, los armeros se beneficiaban también de ello. La nobleza fue la principal beneficiaria de los posibles avances, pues siempre tenían caballo y armas preparados para la guerra. Unas veces luchaban junto al rey, otras se debatían en luchas entre distintos clanes nobiliarios por el poder en sus distintas zonas de competencia, y se entrenaban para ello en las justas o torneos, la esgrima, la caza, etc. Era un aprendizaje militar, y de la función guerrera derivaban la mayoría de las exenciones y privilegios que recibieron ${ }^{13}$.

Los armeros alcanzaron una muy buena aceptación social donde incurría también el hecho de que los miembros familiares siguieran el oficio de sus progenitores, aunque en la época, esta circunstancia era muy frecuente, pero en el caso de los armeros era más que evidente y sirva de ejemplo la familia Martínez, en la que, aparte del seguimiento de la armería, otros hijos realizaron la labor conjunta e imprescindible del forjado, todo abocado a mantener el principal oficio familiar de armero. Entre sus labores, no solo estaban las corazas o armaduras, los cascos y cotas de malla, sino también las armas, aunque hubo otros profesionales dedicados a la fabricación de espadas, lanzas, ballestas, escudos, cuchillos, puñales y dagas, ya que en este período era frecuente que distintos profesionales hicieran labores

11. La collación de San Nicolás de la Axerquía también participaba de la presencia de esgrimidores, como se puede comprobar a través de un documento notarial de 7 de abril de 1496, sobre examen para obtener el título de maestro de esgrima, que dice: "Estando reunidos en la posada del maestro del arte de la esgrima Nicolás, sita en la calle del Potro de la collación de San Nicolás de la Axerquía, y estando presentes los siguientes maestros de esgrima, Alfonso Gandía, el dicho Nicolás, Antón Álvarez, Pedro Ramírez, maestre Miguel y maestre Rodrigo, a fin de otorgar el dicho título a maestre Bartolomé, vecino de la collación de Santiago, para que pueda poner tienda donde quisiere, por virtud del poder que el mencionado maestre Alfonso Gandía tiene del maestre Gómez Dorado, Maestro Examinador Mayor por el Rey y Reina". Habiendo sido previamente examinado en la plaza de la Corredera en presencia de mucha gente y de los dichos maestros, los cuales le encontraron hábil para administrar dicho arte a otras personas. El examen se hizo en domingo. AHPCO, PN 13665P (Escribanía 18), cuad. 28, s. f., 1496-04-07.

12. Para ver más en Leva Cuevas 2004, pp. 107-124.

13. Moxó 1961, p. 165. 
que no pertenecían a su propio campo, es decir, la actividad laboral no estaba tan definida como pueda estarlo actualmente, por ello los armeros podían, como su propio nombre indica, hacer distintas armas ${ }^{14}$.

En el trabajo artesanal de las armas se debe señalar la importancia de los espaderos, dada la impronta de la espada a lo largo de la historia, desde las falcatas de hoja curva y empuñadura a veces decorada, pasando por las de los romanos, las de los árabes, hasta que en los siglos XII y XIII, la espada se convirtió en el arma noble, caballeresca y cristiana. Generalmente son fuertes, con hojas rectas de dos filos, con un canal en el centro casi hasta la punta que suele ser redondeada, con empuñaduras cortas y fuertes, el pomo en forma de nuez del brasil, castaña o esférica, en forma de disco plano o grueso y hasta hueco. El metal es hierro, con frecuencia plateado, o bronce (dorado), puede ser decorado con ornamentación o símbolos grabados o esmaltados, hasta en forma de figuras heráldicas. Se hacían grandes espadas para la guerra y más pequeñas para ceñir, cuando el caballero, elegantemente vestido, está montado a la grupa de su caballo e incluso, preciosas para ceremonias reales, ricamente adornadas con oro, piedras preciosas, etc. Con la espada recibió el espaldarazo el joven caballero que de esta forma pasaba a ser incluido en el orden superior de la caballería, porque según don Juan Manuel, en su libro de los Estados, la espada significa tres cosas: la primera, fortaleza, porque es de fierro; la segunda, justicia, porque corta de ambos las partes; la tercera, la $\mathrm{cruz}^{15}$.

Desde épocas remotas, la espada ha significado el símbolo del hombre libre, llegando, incluso a ser objeto de culto en algunos países paganos, pero entre los cristianos fue el símbolo de Dios, significativo del poder que los reyes recibían de él. Por tanto, las armas, en general, están presentes en la historia política, económica y tecnológica, así como en la religiosa, pues no hay que olvidar el papel jugado por las Órdenes Militares en este contexto medieval. Las mismas espadas de los reyes recibieron nombres, como una de las que poseía Fernando III, "la Lobera", la del Cid, "la Tizona", o "la Colada", que al parecer se trata de la regalada por Fernando el Católico al primer marqués de Falces, condestable de Navarra, Mocén Pierret de Peralta, en agradecimiento por el servicio prestado, o aquellas otras a las que se les atribuye un origen maravilloso como "Excalibur", "Durendal", etc. Así

14. AHPCO, PN 13665P (Escribanía 18), cuad. 4, f. 29v, 1473. El armero Martín Sánchez, vecino de Córdoba, otorga finiquito por haber recibido $4.000 \mathrm{mrs}$. de Miguel Ruiz de Villafranca, que pagó por un alcaide - del que no se conoce su nombre- ya que éste se los debía de ciertas armas que le había comprado. En el documento AHPCO, PN 13666P (Escribanía 18), f. 98r, 1482-12-02, el latonero Antón Ruiz Bocanegra, vecino de la collación de San Nicolás de la Axerquía, tenía unas corazas forradas en cordobanes negros que le había dejado el joyero de la Reina, Álvaro de Carrión, un mes y medio antes, teniéndolas embargadas y que solo podía entregárselas al tal Álvaro y a su criado Julián. Interesa este documento porque describe un tipo de corazas en las que interviene el cordobán, en este caso negro, que recibía un triple tratamiento: teñido, operaciones de quebrantar, remanar y apellar, después era asentado en "agro de limones". Hay que decir que los cordobanes procedían de la piel curtida de cabra o macho cabrío, siendo más gruesos y más caros que las badanas, pues podían costar a fines del siglo XV entre 125 y 150 mrs. Córdoba de la Llave 1990, p. 184. Así pues, las corazas podían ser utilizadas como fianzas para préstamos.

15. Bruhn de Hoffmeyer 1988, p. 41. 
pues, las espadas alcanzaron tal importancia, que algunas serían tan apetecibles como para ser recibidas como merced otorgada por los propios reyes.

Aunque el valor de estas espadas, supone refererirse a las clases privilegiadas de la sociedad medieval, también el pueblo pudo tenerlas, no tan valiosas como las precedentes, como es el caso de la caballería de premia cuando acceden a tal privilegio, que les obligaba a mantener caballo y armas en perfectas condiciones, pero también queda comprobado a través de la documentación notarial en inventarios, obligaciones, finiquitos, préstamos -ya que fueron objeto de empeño-, donaciones, etc. En ocasiones, incluso en un estado más deplorable, ya raídas y oxidadas, que llegaron a estar en venta en las almonedas.

Al estar la espada tan relacionada con el arte de la esgrima, no es de extrañar que esta materia sea recogida en tratados, donde se expone la lista de los mejores fabricantes de hojas de espada que han existido en diferentes partes de los reinos de España, como en el tratado de don Diego Rodríguez del Canto o el de don Francisco de Santiago Palomares, que da noticias en su obra de la famosa fábrica de espadas de Toledo, que durante tantos siglos existió, terminando su periplo a fines del siglo XVII, así como sobre el método que usaron los armeros para forjarlas y templarlas. En 1837, don Antonio Oliver escribió Historia de la esgrima $y$ de los desafios, narrando desde el origen de la espada, que lo encuentra en la época en que los escitas la veneraban como imagen de Marte, hasta el tiempo en que fueron permitidos los desafíos y de las causas que posteriormente llevaron a su prohibición ${ }^{16}$.

Sin olvidar que Córdoba tuvo una escuela afamada de esgrima, que dio pie a la labor de espaderos y armeros, con la ampliación de la demanda de los diversos elementos que necesitaban los esgrimidores y aprendices. Precisamente, el escudo de Armas de los esgrimidores cordobeses, otorgado por los Reyes Católicos llevaba como distintivo una espada o montante bordado en el pecho ${ }^{17}$.

Los espaderos podían comprar hojas de espadas, que completaban perfeccionándolas, a los forjeros de hojas u hojeros ${ }^{18}$. Las ordenanzas de espaderos de Córdoba dejan ver que para poner tienda y ejercer como tales debían saber guarnecer una espada de terciopelo, una de cuero negro, acicalarla y afilarla; guarnecer una espada de cazo de cuero negro o blanco o de otro color; también guarnecer espada de dos manos -la técnica del arte de la esgrima durante los siglos XIV al XVI suponía utilizar las dos manos-; explicar los puntos y cosas requeridas para ir bien guarnecida una espada de la jineta y de todo aquello perteneciente a ella para

16. La amplia bibliografía dedicada a la espada y su aprendizaje a lo largo del tiempo evidencian el papel principalísimo de la misma. Una muestra de esta:

- La Academia de Espada (G. Thibaust 1626).

- Teoría del arte y práctica de la espada (Philibert de la Touché 1670).

- $\quad$ El maestro de armas en el ejercicio de espada (De Liamcourt 1686).

- Desengaño de la espada, y norte de diestros (Cristóbal de Cala 1642).

17. Gestoso Pérez 1911, p. 106.

18. Un ejemplo de ello lo aporta Córdoba de la Llave 1990, p. 267, nota 91: "Gonzalo Rodríguez, espadero, debe pagar a Alfonso Martínez de Mazuela, $1.582 \mathrm{mrs}$. de ciertas hojas de espadas que le compró". Año 1479. 
que sea hecha perfectamente ${ }^{19}$. Los espaderos, como los armeros, eran excelentes artesanos, que experimentaban a fin de evolucionar hasta conseguir espadas perfeccionadas para obtener las mejores cualidades de corte, resistencia, equilibrio y ligereza. Así, también se fueron aligerando al disminuir su grosor hacia la punta, lo que permitía un mayor equilibrio en el manejo de la misma. Se llegaron a fabricar en mayor cantidad y ya de menor calidad para dotar a los ejércitos, pero según las ordenanzas de 1512 , se procuraba que no perjudicaran a los combatientes, ya que les iba la vida en ello.

Las espadas fueron el arma blanca más difícil de hacer, por lo cual se tenía en gran estima a los espaderos más cualificados, y en éste, como en otros oficios, el trabajo pasaba de padres a hijos, sobre todo, si la familia en cuestión tenía gran prestigio como espaderos. La espada era cara igual que lo fue la armadura, solo asequible a nobles y caballeros o a aquellos individuos con cierto poder adquisitivo y la tuvieron aquellos pertenecientes a los ejércitos profesionales; no así los constituidos en las levas en determinados períodos de conflictividad, por lo que, con la excepción de los caballeros de premia, los demás reclutados llevaban lanzas (lanceros), ballestas (ballesteros), mazas, hachas, alabardas (alabarderos), etc., elementos más baratos y más fáciles de fabricar que las espadas.

Se hicieron espadas de gran lujo, con gran riqueza de adornos, pero eran más bien objetos simbólicos para desfiles, ceremonias, pero no para la guerra. La conocida espada ropera aparece por primera vez en el inventario del duque don Álvaro de Zúñiga, en $1468^{20}$.

Existían diversos tipos de espada: moriscas, jinetas y roperas, así como en las ordenanzas se alude también a espadas blancas y negras en orden al cazo y espadas de dos manos. De todas ellas debía mostrar su destreza en fabricarlas el aprendiz de espadero si quería ser considerado maestro y poder abrir tienda.

En este oficio colaboraban otros profesionales aparte del espadero propiamente dicho, como era el ya citado forjero de hojas u hojero, y el vainero, que hacía las vainas. Mientras estos dos últimos solo hacían aquello que daba nombre al oficio, el espadero vendía las espadas completas: conocía las hojas y su calidad, las guarnecía, acicalaba y afilaba. También podía fabricar las vainas para las diversas armas, para lo que empleaba badana, cordobán y becerro, lo que lo relacionaba con los industriales del cuero. Así vendía la espada con un cazo o guarnición, a veces labrada o plateada, un pomo adornado, su vaina de cuero armada con contera y brocal plateados o esmaltados y su tejillo para ceñirla a la cintura ${ }^{21}$.

Hay que decir que el caballero apreciaba su espada tanto como a su caballo, por ello le daba nombre, como ya se ha dicho, y era emblema de sus poderes y privilegios. No solo contaba la espada como labor de los espaderos, pues también

19. Ibid., p. 268, nota 92 .

20. Peláez Valle 1988, pp. 147-199.

21. Córdoba de la Llave 1990, p. 268. AHPCO, PN 13666P (Escribanía 18), ff. 392v-393r, 148603-13. Gonzalo de Portugal, hijo de Juan de Portugal, vecino de la collación de Santa María, debe pagar a Antón Moñiz, espadero, vecino de la de San Nicolás de la Axerquía, 11 reales de plata de cierta mercadería que le compró. 
las dagas y puñales conformaban parte de su labor. Las buenas armas, como los buenos caballos, costaban caras. Éstas se estropeaban fácilmente y pasaban de moda, y así como se perfeccionaban las técnicas del combate, se obligaba el propio caballero a procurarse nuevas armas.

Pese a la importancia de la espada, es destacable otra arma que igualmente tuvo un papel importante en las guerras de los siglos XII y XIII, la lanza, que tras usarla como jabalina, advirtieron que era mejor cargar contra el enemigo manteniéndola en la mano horizontalmente, al trote del caballo, aumentando así la fuerza de penetración, por lo que se hicieron más largas y gruesas. Además de su utilización en las guerras, tanto por los caballeros como por los lanceros a pie, se usaron en los torneos, en la caza, en los juegos de cañas, etc., que en Córdoba, se llevaban a efecto dichos juegos, corridas de toros, torneos y esgrima, en la plaza de la Corredera, lugar de gran vitalidad para la ciudad dada la afluencia de público $\mathrm{y}$ viandantes.

Algunos pecheros podían tener tanto lanzas como espadas y no solo los caballeros, ya que aquellos participaban en las levas que los reyes solicitaban para sus campañas militares, como eran los lanceros, por lo cual no es extraño hallar en los inventarios piezas de este tipo. Tal es el caso de un sastre, Antón Rodríguez de Baena, que en vida residió en San Nicolás de la Axerquía y en cuyo inventario se detallaba que poseía una lanza ${ }^{22}$.

El armamento constituyó en esta época un elemento imprescindible desde el más elemental cuchillo, puñal o daga, hasta la más sofisticada armadura y espada, pasando por el escudo, la ballesta y la lanza. Esta última proporcionó a sus fabricantes, los asteros, una holgada economía, con la familia, que participaba en el negocio de manera directa o indirecta. Mantenían relaciones con mercaderes vascos, incluso venían desde allí trabajadores del oficio de la astería. La presencia de profesionales vascos se veía favorecida por ser Córdoba en esos tiempos una sociedad de frontera, donde llegaron los reyes, el séquito real y todos aquellos que hacían de esta vida errante y mercenaria, amén de profesionales, su modus vivendi.

Con el nombre de ballestero se designaba al trabajador que fabricaba las ballestas y al que las utilizaba en el ejército y en la actividad cinegética. En referencia a los primeros, estos trabajadores precisaban de materiales tales como la madera, el metal y cuerdas de cáñamo, tripa o nervios (textil y cuero), y en esta última materia se dieron profesionales como el maestro de hacer hilo de ballestas, Bernal Francés -apellido posiblemente relacionado con su origen-, vecino de esta ciudad, que recibe en 1499 a un aprendiz del oficio ${ }^{23}$. Existió una versión cordobesa de estas ballestas en el siglo $\mathrm{XV}^{24}$. Pese a dicho uso tan común no proliferaron los ballesteros, pues es mayor la presencia de armeros y espaderos, incluso de asteros.

Los cuchilleros, cuyas ordenanzas fueron redactadas en 1519, formaron parte también de este mundo de las armas, aunque abarcaron otros ámbitos donde se requirieron sus servicios para realizar los instrumentos que necesitaban otros pro-

22. AHPCO, PN 13666P (Escribanía 18), ff. 476r-v, 1486-06-27.

23. Córdoba de la Llave 1990, p. 269, nota 95.

24. Para conocer más, consultar Córdoba de la Llave 1990, pp. 268-269. 
fesionales, como las tijeras para barberos, sastres, zapateros y escribanos (guarniciones de escribanía: tijeras, cuchillo y punzón). Todo ello debido a que el oficio de cuchillero se dividía en tres especialidades: el arte de la cuchillería propiamente dicho, el arte de lo buido ${ }^{25}$ y el arte de la menudería. No obstante lo que interesa para este estudio es el uso como posible arma de cuchillos, puñales, dagas, etc., aunque todo lo anterior vaya unido.

El proceso de fabricación de estos instrumentos pasaba por dos fases: la del forjado de hojas y cuchillas y la del guarnecido de la hoja, donde podían participar elementos, tanto de hierro como de cuero.

Los adargueros fabricaban las adargas, que completaban el equipo del caballero. Éstas eran los escudos redondos u ovalados que lo protegían, así como para los infantes existía otro oblongo y mayor que los anteriores, a los que le cubría el cuerpo, llamado "pavés". En su fabricación se utilizaba el cuero, especialmente el encebro (piel perteneciente a caballos salvajes), anta, cervuna, etc. La ordenanza de correeros de Sevilla de 1488, a la que se refiere Córdoba de la Llave, en su obra La Industria Medieval de Córdoba, y en la que este oficio estaba incluido, decía cualquier maestro que hiciere adarga, que sea de buen cuero, bien adobado... y el adarga que hiciere de encebro que la haga de lomo y su sobrelomo de cuero muy bien curtido $^{26}$. Iban asentadas las pieles sobre moldes de madera o metal, dando lugar a dichas adargas o paveses. Y no hay que olvidar que el cuero estuvo presente en la industria del armamento, como en las corazas, las vainas de las espadas y cuchillos, y en los mangos de éstos.

Por consiguiente, la industria armamentística en este período analizado, tuvo un papel importante, como exponía el armero Martín de Aragón, al solicitar al ayuntamiento que dicho oficio tuviese ordenanzas como las tenían otras actividades artesanales. Más aún tratándose de un oficio de calidad e importante para defender las vidas de los hombres, sobre todo cuando la violencia estaba tan enraizada en una sociedad de guerras, conflictos y fronteras, y cuando las armas constituían un concepto de diferenciación social y de fiscalidad ${ }^{27}$.

\section{Porcentajes de los oficios del armamento}

Los armeros en Córdoba, según los Protocolos Notariales, representaron el 9,4\% de la rama del metal, ocupando en ella el sexto lugar, tras los oficios de calderero $(16,4 \%)$, herrero $(15,4 \%)$, cuchillero $(13,2 \%)$, herrador $(11,6 \%)$ y cerrajero $(9,7 \%)$. Los armeros estaban muy cercanos en porcentaje a un oficio tan importante y necesario como el de cerrajero, y además, en esta industria del armamento, solo fueron superados por los cuchilleros, que unían en su entramado laboral, no solo instrumentos defensivos como puñales, dagas o los propios cuchillos, sino

25. Estos oficiales debían hacer un examen especial, y no podían trabajar en esta faceta si no lo habían superado. Córdoba de la Llave 1990, p. 266.

26. Ibid., p. 208, nota 126.

27. Así titulaba un artículo Bernal Estévez 1988, pp. 21-30. 
además instrumentos laborales y domésticos. Esto explicaría el mayor número de estos profesionales, cosa que no sucedía con los armeros, dedicados exclusivamente a la protección y a las armas.

El padrón cordobés de 1509 expone una concentración de armeros en la collación de San Nicolás de la Axerquía, en la calle Armas, donde residían. Solo se ha localizado un armero más en la de San Andrés, hecha la salvedad, ya mencionada, de que solo se han conservado seis collaciones en dicho padrón.

En la documentación de los Protocolos Notariales del Archivo Histórico Provincial de Córdoba, los armeros representaron el 18,9\% de la rama del metal en dicha collación de San Nicolás de la Axerquía, que a su vez suponían el 50\% de los armeros cordobeses. Esta mayor concentración de armeros en la collación coincide también con los datos obtenidos del citado padrón de 1509. Continuando con los Protocolos Notariales, además de esta collación, las de San Andrés, con el 42,9\%, y la de San Pedro, con 7,1\%, son las que suponen la totalidad de los armeros de Córdoba.

Sin olvidar que la rama del metal alcanzó el tercer lugar en la industria artesanal, tanto en Córdoba como en esta collación de San Nicolás de la Axerquía ${ }^{28}$.

La importancia de la espada era evidente y sus artesanos, los espaderos, se vieron beneficiados por la misma, sustanciado en más trabajo para sus talleres y, especialmente, de aquellos más cualificados, aunque no llegaron a alcanzar el porcentaje de los armeros, siendo el de estos espaderos el 4,1\% de la rama del metal en Córdoba, quizás debido a que los armeros también hacían espadas. Los espaderos en la ciudad de Córdoba, según los Protocolos Notariales, se concentraron en dos collaciones, aunque mayormente en la de San Nicolás de la Axerquía, con un $83,3 \%$, y el resto $(16,7 \%)$ en la de San Andrés y, además, el Padrón de 1509, aunque no se conserve íntegro, aporta el número de espaderos residentes en la primera. Así en la calle del Potro hay dos espaderos -Luís López y Luís de Carrera- y en la Plazuela de la Caridad ${ }^{29}$, otros dos -Francisco García y Juan López-, siendo cuatro en total. En la de San Andrés, en la calle Mayor hacia San Pablo, dos espaderos, Pedro Fernández y Juan de Cea. Se mantiene la mayor residencia en la primera collación de las mencionadas. Según este padrón, también se localizaban espaderos en la collación de San Pedro: en la calle de la Odrería, actual Sánchez Peña, residía Juan Catalán y en la calle del Baño, otro, Juan López Chaparro. Esta última calle estaba próxima a la iglesia de San Pedro, y desembocaba en la acera norte de la calle del Potro, en el tramo llamado Caño de Vecenguerra (sería la actual Carlos Rubio). En esta última collación se observa que los espaderos residían en la zona más próxima a la collación de San Nicolás de la Axerquía, buscando la cercanía a ella, posiblemente por trabajar en algún taller de la mencionada collación o porque la proximidad entre los espaderos podía conducir a una mayor demanda y comercialidad.

28. Sobre los oficios artesanales se pueden ver Córdoba de la Llave 1991; Escobar Camacho 1989, pp. 292-314; Leva Cuevas 2000, pp. 20-28.

29. Dicha plazuela, donde estaba el hospital de la Caridad, correspondería a la llamada plaza del Potro, pero en 1509 era conocida con dicho nombre según el mencionado padrón. 
La collación de San Nicolás de la Axerquía era la principal en cuanto a lugar de residencia y trabajo de los asteros, pues el $80 \%$ se concentraban en ella, repartiéndose el resto entre Santa María (10\%) y San Pedro (10\%). Buscan siempre el entorno próximo al lugar de su concentración y de salida de sus obras, ya que las dos últimas collaciones también tenían entidad propia en la comercialización de todas las mercancías de la ciudad. El porcentaje alcanzado por los asteros en Córdoba y en la rama del metal, el 3,1\%, es muy próximo al de los espaderos, $4,1 \%$, lo que indica que la demanda de una u otra arma es muy parecida debido a su utilización indistintamente y por igual. En el padrón de 1509, de las seis collaciones conservadas, entre ellas las de San Nicolás de la Axerquía y San Pedro, no se menciona a ningún astero, pero sí armeros, espaderos y ballesteros.

Así pues, San Nicolás de la Axerquía sigue siendo la collación armamentística por excelencia, ya que también los asteros se concentraron en ella.

Según los Protocolos Notariales, los ballesteros alcanzaron en toda la ciudad el $1,3 \%$ de la rama del metal, frente al $13,2 \%$ que suponen los cuchilleros, armeros $(9,4 \%)$, espaderos $(4,1 \%)$ y asteros $(3,1 \%)$. En estos porcentajes no se incluyen los malleros porque solo se ha localizado uno, Alfonso García, que actuaba en 1486; pero hay que tener en cuenta que los armeros también hacían mallas, por lo que fueron menos los profesionales dedicados exclusivamente a esta confección. Así se ha comprobado en las Ordenanzas de 1512, en las que se citan los armeros que también confeccionaban mallas:

- Pedro Fernández de Alcántara.

- Martín de Aragón.

- Pedro Gómez.

En estas ordenanzas también se menciona un solo mallero, como en el citado caso de protocolos, que reside en las Tendillas de Calatrava, sin constar su nombre.

A continuación se exponen los gráficos de porcentajes y comparativo de los oficios del armamento.

OFICIOS DEL ARMAMENTO RESPECTO A LA RAMA DEL METAL

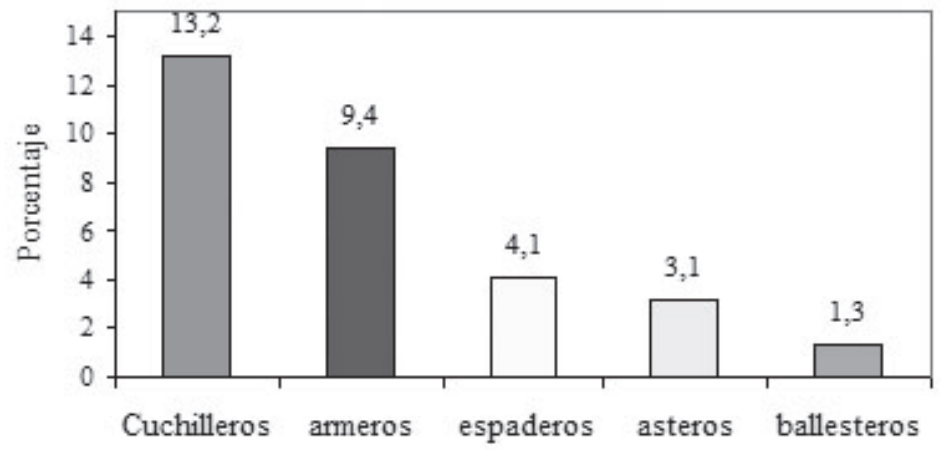

Gráfico 1. Porcentajes de los oficios del armamento respecto a la rama del metal. 


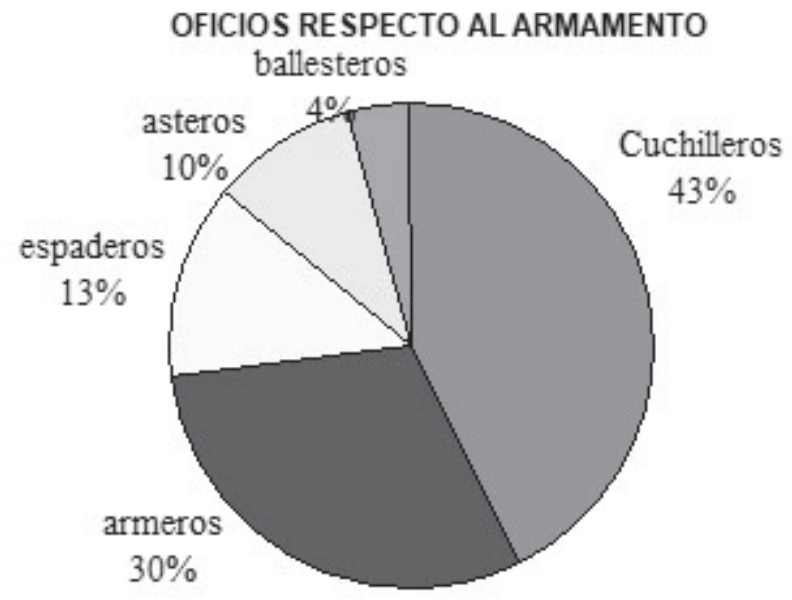

Gráfico 2. Porcentajes de los oficio del armamento.

En los Protocolos Notariales se localiza el 75\% de los ballesteros residiendo en la collación de San Pedro y el 25\% restante en la de San Lorenzo. Por el padrón de 1509 , se sabe que de los cuatro ballesteros que cita, dos residían en la collación de San Pedro, uno en San Nicolás de la Axerquía y otro en San Miguel. Por tanto, sigue siendo la primera, la principal área de residencia y trabajo de éstos, como en los tres anteriores casos: armeros, espaderos y asteros, lo era la de San Nicolás de la Axerquía, contigua a la de San Pedro.

Tres ballesteros del padrón de 1509 se situaban en la calle de la Feria, cerca de los cuchilleros y vaineros. Así pues, concentración en esta calle, en los dos tramos de la misma pertenecientes a las dos collaciones, San Pedro y San Nicolás de la Axerquía.

Hay que agregar que en este padrón, el número de ballesteros se corresponde con el mismo número de armeros, que residían en la collación de San Nicolás de la Axerquía. Los espaderos se concentran en la misma collación de San Nicolás de la Axerquía y duplican a cada una de las dos profesiones anteriores -siempre según el padrón, pues no sucedía igual en los Protocolos Notariales, donde los armeros superaban a los espaderos-. Son los cuchilleros los que en mayor número se han localizado, 13, de los que 12 residían en la collación de San Pedro, en la calle de la Feria entre los cuchilleros. Los propios Protocolos Notariales marcan igualmente el mayor porcentaje de cuchilleros frente a los demás oficiales del armamento.

Los cuchilleros representaron en la rama del metal cordobesa el 13,2\% de los profesionales de la misma, el tercer lugar, tras los caldereros $(16,4 \%)$ y los herreros $(15,4 \%)$, y frente al de la armería con el 9,4\% que pasa a ocupar el segundo lugar de esta industria armamentística.

La collación elegida como lugar de residencia y trabajo fue la de San Pedro con el $82,1 \%$, y ya muy por debajo las de San Lorenzo (7,1\%) y San Juan (3,6\%). Un 
$7,1 \%$ de los cuchilleros figuraba como estante. Como en los otros casos de fabricantes de armas, pudieron venir atraídos por ser Córdoba una ciudad fronteriza e importante durante el bajomedievo.

Según el padrón de 1509 los cuchilleros eligieron dentro de la collación de San Pedro, la calle de la Feria para su residencia y trabajo, en el tramo perteneciente a la misma, como se dice en dicho padrón: calle de la Feria desde el pilar. Se refiere al pilar de agua que había junto al convento de San Francisco o de San Pedro el Real, hacia arriba, pues la otra parte de la calle pertenecía a San Nicolás de la Axerquía. En total eran doce cuchilleros avecindados en la misma, entre los que destacaba Juan Gaciret, cuchillero fidalgo. Así pues, concentración de estos profesionales en dicha calle. Además, en la documentación notarial, cuando se aludía a la residencia de alguno de ellos en la citada calle, se indicaba entre los cuchilleros.

Los vaineros y adargueros pertenecen a la rama del cuero pero complementan a la industria del armamento. El primero de estos oficios, incluso fue ejercido en ocasiones por los mismos cuchilleros, para ampliar su campo de actuación y completar su principal labor. Aquellos dedicados solo al oficio de vainero, representaron en la rama del cuero cordobesa el 3,1\%. Los adargueros, dedicados a fabricar las adargas o escudos redondos u ovalados, realizados con cuero, alcanzaron un porcentaje menor al anterior $(0,8 \%)$ en dicha rama. Y en el padrón de 1509 solo se ha localizado un adarguero residiendo en la calle de la Sillería en la collación de San Nicolás de la Axerquía. En los Protocolos Notariales también informan que residieron en dicha calle, por tanto, en ambos casos existe concentración preferente en la calle en cuestión. Los vaineros eligieron concentrarse junto a los cuchilleros en la calle de la Feria entre los cuchilleros, en el tramo de la collación de San Pedro, así pues, según el padrón de 1509 fueron cuatro los vaineros residentes en dicha calle: Juan del Águila, Francisco Sánchez, Alonso Hernández Beteta y Juan de Segura.

\section{Aprendizaje De LOS OFICIOS}

En los oficios del armamento, como en cualquier otro de la época, se daba una jerarquización laboral: maestro, oficial y aprendiz. El primero conformaba la cúspide, tratándose de los menestrales mas experimentados de la profesión, con conocimientos superiores a los de cualquier otro, es decir, tenían la maestría, a lo que podían unir una serie de factores económicos relativos a la propiedad de los medios de producción, herramientas o útiles de trabajo y el taller o tienda, y la tenencia de su propio equipo.

La documentación manejada no siempre aporta la categoría profesional en cuanto a maestros y oficiales; sí en cambio en los aprendices a través de los contratos de aprendizaje, donde se reflejan los maestros y aprendices, y es uno de los aspectos más interesantes sobre la transmisión del oficio en la organización laboral de dicho tiempo. Normalmente no se señalaban las etapas del aprendizaje, solo 
los años que duraba y durante los cuales pasaba a vivir con el maestro y su familia, como igualmente sucedía con las mozas de servicio en el caso de las mujeres.

En la primera parte del texto se presentaban los intervinientes. Los contratos más frecuentes se daban cuando el aprendiz era menor de edad y el padre asumía la representación legal, o si era huérfano, la madre $u$ otro miembro familiar adulto asumía dicha representación. También se dieron los contratos realizados por los propios aprendices, ya adultos. Después se citaba el nombre del aprendiz, normalmente se reseñaba la edad, sobre todo cuando era menor, y a continuación el nombre del maestro y oficio a aprender, lugares de residencia de ambos intervinientes y el tiempo de duración del aprendizaje. La parte más importante del contrato era la dedicada a las obligaciones del aprendiz y del maestro. Para el primero, el compromiso de trabajo de servir al maestro en las cosas que le mandare y que fuesen lícitas y honestas de hacer, y de no abandonarle (quizás motivado por el trato recibido o porque hubo gran competencia entre los profesionales del oficio y debía ser frecuente dicho abandono ante mejores expectativas), por lo que solía pedirse un fiador a fin de que propiciara la vuelta del aprendiz, aunque ésta no siempre fue solicitada por el maestro.

El maestro también tenía unos deberes para con el aprendiz, de manutención, vestido y calzado, durante el tiempo del aprendizaje, cama y vida razonable que lo pueda bien pasar. Esta parte va unida a lo anterior con referencia al abandono del aprendiz, y si la vida aportada por el maestro no era buena. Después se señalaba la enseñanza de la profesión, que le ha de mostrar el oficio de... El tiempo era variable según la mayor o menor dificultad de cada oficio y la edad de dicho aprendiz. En ocasiones, se especificaban las distintas facetas del oficio a enseñar.

Al final del período de aprendizaje, el maestro debía dar al aprendiz un equipamiento de indumentaria y calzado, detallándose las prendas a entregar con el calificativo de nuevas. También podían añadirse herramientas del trabajo, incluso en algunos oficios, cuadernos de la enseñanza del mismo, y también, en otros casos, una aportación monetaria como pago al servicio prestado por el aprendiz. Los maestros podían recibir, en ocasiones, un pago por la enseñanza dada, o bien un tiempo de servicio gratuito posterior al aprendizaje o bajo una contribución salarial moderada. Una forma de tener mano de obra más barata bajo la fórmula del contrato de aprendizaje.

En la documentación consultada de los Protocolos Notariales cordobeses sobre los oficios del armamento, se encuentran contratos de aprendizaje de algunos de estos oficios, como los armeros, espaderos, cuchilleros y vaineros, pues en este último caso estuvieron muy unidos, ya que hubo cuchilleros que buscaron aprender el oficio de vainero, completando así los útiles y sus fundas.

A continuación algunos ejemplos de contratos de aprendizaje de armeros. El armero Antón, hijo de Juan de Córdoba, vecino de la collación de San Andrés, acoge como aprendiz a Juan de Sanlúcar, hijo del albañil Alfonso Ruiz, vecino de San Miguel, durante dos años y medio, con el avituallamiento y alojamiento habitual de otros contratos de aprendizaje y al final de dicho tiempo reciba el aprendiz como pago del servicio que haya hecho, un jubón, un sayo, una capa de 
paño quince de color, todo nuevo. Las sanciones correspondientes caso de incumplimiento por las partes, eran de $2.000 \mathrm{mrs}$. Este documento aporta las edades de ambos contratantes: el armero dice ser mayor de 22 años y el aprendiz mayor de 15 y ambos menores de 25. Otro armero, Juan Rodríguez, hijo del también armero Diego Alfonso, vecino de San Andrés, toma por aprendiz a Diego, hijo de Fernando el Paje, vecino de San Pedro, siendo este último el que realiza el contrato con el fin de que el hijo aprenda dicho oficio durante un año, en el que se incluyen las mismas condiciones de este tipo de $\operatorname{contratos}^{30}$. También hay armeros que buscan a otros profesionales para que sus hijos puedan aprender oficios distintos al suyo ${ }^{31}$, como el armero Alvar Fernández, vecino de la collación de San Andrés, que pone a su hijo Cristóbal, de 15 años de edad, con el albeitar y herrador Pedro Martínez, vecino de la misma collación, para que le enseñe su oficio durante cuatro años, con las condiciones habituales y al final le de un sayo de paño 18 y un traslado de un cuaderno del albeicería de las preguntas que pertenecen al dicho oficio. En este caso el padre se preocupaba de que recibiera el cuaderno o libro referente al oficio para que le sirviera de consulta ante cualquier circunstancia veterinaria que se le presentara en su vida laboral, es decir, no solo la práctica, sino también la teoría era importante, lo que pudo suceder en otros oficios como el de cirujano, barbero, boticario, pintor, especiero, platero, e incluso el suyo propio de la armería, de ahí dicha preocupación. En este caso de los armeros existe la constancia de familias que realizaban, solos o en compañía, contratos de aprendizaje, pues entre sus miembros había armeros y hojeros -éstos forjaban las hojas de las espadas-, que acogían a individuos para aprender ambos oficios conjuntamente. Sirve de ejemplo una familia constituida por armeros: el padre, Juan Martínez, un hijo, Pedro Martínez, otro posible hijo, Alfonso Martínez, así como otro hijo, Gonzalo Martínez, que ejercía de hojero, todos residentes en la collación de San Nicolás de la Axerquía ${ }^{32}$.

30. AHPCO, PN 14104P (Escribanía 14), ff. 9r-v, 1461-11-17; AHPCO, PN 13665P (Escribanía 18), cuad. 27, s. f., 1495-08-12.

31. AHPCO, PN 13666P (Escribanía 18), ff. 231v-232r, 1483-07-04,

32. Contratos en los que actúan conjuntamente AHPCO, PN 14104P (Escribanía 14), ff. 13r-14r, 1460-03-04; AHPCO, PN 14104P (Escribanía 14), ff. 14r-15v, 1460-03-04. En el primero el aprendiz Juan de Valsalobre, es mayor de 25 años y proviene de la villa de Vélez, para aprender el oficio de armero y hojero, durante dos años y medio, en los cuales los maestros le han de dar de comer y beber razonablemente, cama y $1.100 \mathrm{mrs}$. para vestirse y calzarse durante el mismo -en este caso, en lugar de las prendas se prefiere el dinero o bien encubre un trabajo remunerado bajo el calificativo de aprendiz y salario menor al otorgado a un asalariado u oficial-. En el segundo, el aprendiz Juan de Gahete era vecino de San Nicolás de la Axerquía, mayor de 17 años y menor de 25, "jurando en la forma acostumbrada de no ir en contra del contrato aludiendo a ser menor de dicha edad bajo pena de excomunión" -la religión y su influencia en la vida laboral-. La duración del contrato con dichos maestros era de dos años y medio y con las mismas condiciones del anterior, exceptuando el importe para vestir y calzar, que en este caso era de 1.200 mrs. En ambos documentos actúan como testigos, entre otros, dos hojeros, Pedro de Córdoba y un tal Bartolomé, criados del dicho armero Juan Martínez. El hijo hojero interviene también en contratos de aprendizaje de forma individual como en el AHPCO, PN 14104P (Escribanía 14), ff. 32r-33v, 1464-06-28, en el que el aprendiz era un vecino de la collación de San Lorenzo, durante cuatro años. 
En cuanto a los espaderos, como se vio al analizar el oficio, sus ordenanzas en Córdoba indican que para que estos profesionales pudieran poner tienda y ejercer, debían demostrar mediante examen que sabían

guarnecer una espada de terciopelo, una de cuero negro, acicalarla y afilarla, guarnecer una espada de cazo de cuero negro o blanco o de otro color, guarnecer espada de dos manos, sepa explicar los puntos y todo aquello requerido para guarnecer bien una espada de la jineta y sea hecha perfectamente ${ }^{33}$.

Así pues, tenían que pasar previamente por un período de aprendizaje. Se dispone de diversos documentos notariales de este tipo de contratos. En uno de ellos, Juan Rodríguez de Xerez, espadero, hijo del también espadero Diego Alfonso, vecino de la collación de San Andrés, recibe como aprendiz a Francisco, de 12 años, hijo de Lucía Martínez, viuda de Antón López, vecina de la Magdalena, para aprender dicho oficio. Se anexionaban las condiciones habituales en este tipo de contratos: alimentación, vestido, calzado y lo acoja en su casa dándole una vida razonable durante el tiempo del aprendizaje, y al final del mismo, equipamiento de vestido y calzado nuevos ${ }^{34}$.

En otro contrato de aprendizaje, un foráneo, portugués de la villa de Alcobaz, mayor de 25 años, ve la oportunidad de aprender este oficio, o bien de perfeccionarlo, o la forma más fácil para ser contratado con el menor coste para el maestro. Se trata de Alfonso Portugués, hijo de Juan Pérez, que entra con el espadero Diego de Prado, durante año y medio, al que solo debía mantener en su casa con alimentación, vestimenta y calzado, pero ni siquiera se agrega equipamiento alguno al finalizar el aprendizaje ${ }^{35}$, la necesidad podía estar en el origen del contrato. Otro portugués, Gonzalo de Portugal, vecino de Santa María, relacionado comercialmente con el espadero, Antón Muñiz, vecino de San Nicolás de la Axerquía, al que le compra mercancía, deja ver, junto con el anterior, que pudo haber en Córdoba una población de dicho origen relacionada con la fabricación de armas, especialmente espadas, y su comercio entre ambas zonas ${ }^{36}$.

Otro aprendiz de espadero, también foráneo, Aparición de Mayorga, de Mayorga (Valladolid), entra con el espadero Antón Núñez, vecino de San Nicolás de la Axerquía, durante tres años y medio, y con las mismas condiciones de los anteriores aprendices ${ }^{37}$. Aunque éstas tampoco varían mucho cuando el mismo espadero contrata un asalariado ${ }^{38}$, Isidro de León, hijo de Rodrigo de León, natural de León, durante cuatro meses. El pago consistía en darle de comer, beber, cama, y le haga lavar los camisones y al final del tiempo le de un sayo de grana colorado con caireles de grana colorados. Así el mencionado espadero se había provisto de una mano de obra barata, como era el aprendiz del documento anterior y el obrero

\footnotetext{
33. Córdoba de la Llave 1990, p. 268, nota 92.

34. AHPCO, PN 13665P (Escribanía 18), cuad. 29, ff. 51r-v, 1497-07-05.

35. AHPCO, PN 13665P (Escribanía 18), cuad. 30, ff. 58r-v, 1498-09-25.

36. AHPCO, PN 13666P (Escribanía 18), ff. 392v-393r, 1486-03-13.

37. AHPCO, PN 13666P (Escribanía 18), ff. 474v-475r, 1486-06-20.

38. AHPCO, PN 13666P (Escribanía 18), ff. 817r, 1487-09-26.
} 
de éste. De nuevo se observa cómo la participación de foráneos en la industria del armamento, concretamente de las espadas, estaba muy presente en la documentación analizada.

Pero ello no quiere decir que dicho espadero tuviera una situación económica débil que le obligara a tal tipo de contratación, pues en la documentación referente a dotes, hay casos de espaderos como un tal Andrés Fernández, que recibió de dote 50.000 mrs., 40.000 en ajuar y 10.000 en metálico. Esta cuantía en metálico supone el $20 \%$ del total de la dote, que solía ser muy deseada, ya que el marido podía disponer de ella para diversos fines, contribuyendo así la esposa con una aportación sustanciosa que podía estar en consonancia con la posición socioeconómica del marido, o beneficiaría muy sólidamente a la carga de dicho matrimonio ${ }^{39}$.

En los contratos de aprendizaje de cuchilleros encontrados en la documentación se puede observar que el tiempo de duración suele estar comprendido entre dos y cuatro años, según la edad y la enseñanza que quiera recibir el aprendiz ${ }^{40}$. En algunos casos éste continuaba trabajando con el maestro, con el consiguiente beneficio para éste, que paga menos cuantía por el trabajo realizado, puesto que el aprendiz continúa figurando como tal. De los contratos analizados, un $60 \%$ de los aprendices procedían de fuera del reino cordobés, de lugares tan diversos como Santander, Salamanca, Villarreal, Lora, Galicia o Toledo.

Entre los maestros cuchilleros más solicitados estaban: Benito González, vecino de la collación de San Pedro, y Juan de Soria, residente en la misma collación. Este último actuaba como tal maestro en la década de los ochenta del siglo XV. Llegó a Córdoba en 1475, procedente de Soria, a trabajar a soldada con el cuchillero Alfonso Rodríguez, igualmente vecino de la misma collación (en ese momento se indicaba en el documento que era mayor de 15 años y menor de 21$)^{41}$. En menos de un año se instaló con tienda en Córdoba, acogió aprendices y llegó a ser reconocido como maestro muy solicitado.

La enseñanza consistía en, como se dice en alguno de estos contratos, que le enseñe su oficio del tablero de todas las obras que se usan e usaren en esta ciu$d a d^{42}$. En todos los contratos consta el mantenimiento, vestuario y calzado que el maestro debía proporcionar al alumno durante el tiempo de su duración, y al final del período, un equipamiento de vestuario y calzado, todo nuevo y, en algunos casos, acompañado de una cuantía monetaria ${ }^{43}$, que podía oscilar entre los $1.000 \mathrm{y}$

39. AHPCO, PN 13665P (Escribanía 18), cuad. 4, f. 34v, 1473-10-08.

40. Córdoba de la Llave 1990, p. 266, nota 86: ... Alfonso, natural de la Puebla de Alcocer entra como aprendiz con Antón Ruiz, cuchillero, el cual le enseñará durante los dos primeros años "el tablero, a hacer y guarnecer puñales barnizados y de trabajo" y en otro año "a forjar en la fragua cuchillas de puñales". Se confirma cómo los puñales estuvieron muy presentes en el oficio de cuchillero.

41. AHPCO, PN 13665P (Escribanía 18), cuad. 7, f. 20r, 1475-02-13. El contrato duraba desde la fecha del mismo hasta el día de Santa María de agosto siguiente, pagándole $1.000 \mathrm{mrs}$., y comida, bebida, cama y los zapatos que necesitara. Actuaron como testigos los también cuchilleros y vecinos de Córdoba, Pedro de Cazorla y Juan de Castro del Río.

42. AHPCO, PN 14104P (Escribanía 14), ff. 98v-99r, 1460-11-05.

43. AHPCO, PN 14104P (Escribanía 14), ff. 104r-105r, 1460-11-25. "Quinientos mrs. por el servicio prestado", señal de ese trabajo que hacía el aprendiz y que excedía al mero aprendizaje. En el contrato AHPCO, PN 14104P (Escribanía 14), ff. 105v-107r, 1460-11-28, se daban al aprendiz 1.300 
los 2.000 mrs. por las labores que realizaban. Trabajo escondido en el aprendizaje, no muy lejos de lo que sucede en el trabajo precario actual. A veces, también pudieron combinar, al mismo tiempo, soldada y aprendizaje, como quedó expresado anteriormente.

Algunos cuchilleros quisieron intervenir en la fabricación de vainas de cuero para puñales y cuchillos, al mismo tiempo que hacían éstos, ampliando así su campo de acción como ya se ha visto con otros profesionales, a fin de asegurarse el aporte económico que podía derivar de la fabricación de ambas piezas, favoreciendo también al propio cliente, que podía adquirir ambos en el mismo lugar. Por ello no es extraño hallar contratos de aprendizaje como el siguiente: Juan de Valladolid, cuchillero, estante en Córdoba, entra como aprendiz con el vainero Sancho Gómez, vecino de la collación de San Pedro, para que le enseñe su oficio durante dos años, recibiendo alimentación, vestimenta y calzado durante dicho tiempo ${ }^{44}$.

En el caso de los aprendices de ballesteros sucedía igual que en los demás contratos de aprendizaje e, incluso, después de conocer la materia, podían tener un interés especial en una determinada faceta más específica de la misma, como un especialista más formado. Es el caso de Juan Alfonso, que entra como aprendiz

mrs. para vestuario y calzado durante el período de aprendizaje, que era de tres años, aparte de alimento y cama. En estos dos contratos expuestos, el maestro cuchillero era Benito González, uno de los más solicitados. En AHPCO, PN 13666P (Escribanía 18), ff. 582v-583r, 1487-01-08, el otro de los también solicitados, Juan de Soria, hizo un pago de $1.000 \mathrm{mrs}$. y un par de borceguíes al final del aprendizaje de Antón de Villarreal. O casos curiosos como en AHPCO, PN 13666P (Escribanía 18), f. 756v, 1487-0726, donde el aprendiz originario de Lora, Gonzalo Rodríguez, entraba con el maestro cuchillero Antón de Cea, vecino de San Pedro, durante dos años y medio, recibiendo en dicho tiempo comida, bebida, vestimenta y calzado, y "mediado el tiempo, $500 \mathrm{mrs}$. y otros 500 al final", y estos $1.000 \mathrm{mrs}$. los paga a Cristóbal Romero, cuchillero, vecino de Sevilla, y que a la vez actuaba de fiador. Deja ver un débito del aprendiz al cuchillero sevillano, que en vez de trabajar con éste para saldar la deuda, lo hace con el cuchillero cordobés citado, y no solo como aprendiz. O en AHPCO, PN 13669P (Escribanía 18), ff. 347v-348r, 1493-11-12, en el que se alude, tanto a soldada como a aprendizaje: Fernando de Lugo, cuchillero de la menudería, natural de Galicia, entra a soldada con Juan de Córdoba, cuchillero, hijo de Juan Rodríguez, residente en la collación de San Pedro, para que "le enseñe su oficio de cuchillero, a hacer tijeras y cuchillos", durante un año, y le de comida, bebida, cama, cuatro pares de zapatos, dos camisones de lino tiradizo, todo nuevo, y 60 reales de plata $(2.040 \mathrm{mrs}$.). Durante el tiempo que trabajaba para el maestro, de su especialidad de la cuchillería dedicada a labrar piezas menudas como las guarniciones de escribanía, o de cubertería para la mesa, etc., aprendía también otras labores del arte de la cuchillería o el arte de lo buido o de rodete. Este último requería superar un examen especial para poder actuar como maestro de dicho arte, así por tanto recibía lo propio de un aprendiz y de su trabajo la soldada mencionada. Un recorrido interesante por el mundo contractual del aprendizaje y del trabajo de la cuchillería.

44. AHPCO, PN 14104P (Escribanía 14), f. 9v, 1461-11-18. El aprendiz reconocía ser mayor de 22 años y menor de 25. Actuaron como testigos gentes de ambos gremios: Alfonso, cuchillero, hijo del también cuchillero Fernando López, Alfonso de Córdoba, cuchillero, hijo de Fernando Sánchez, y Fernando Portugués, vainero, todos vecinos de San Pedro. En muchas ocasiones, los oficiales del gremio al que pertenecían los contratantes actuaban de manera solidaria, como en este caso, de testigos. Lo mismo se puede ver en otros contratos: AHPCO, PN 14104P (Escribanía 14), ff. 105v-107r, 146011-28, es una carta de aprendizaje con el maestro cuchillero Benito González, donde actuó de testigo, entre otros, un tal Gómez, cuchillero, familiar del arcediano de Castro; en AHPCO, PN 13665P (Escribanía 18), cuad. 7, f. 20r, 1475-02-13, actuaron de testigos dos cuchilleros para afianzar un contrato de trabajo igualmente entre cuchilleros. También estuvieron presentes como testigos en obligaciones, donaciones, préstamos, dotes, poderes, ventas de viñas, alquileres de casas-tienda, testamentos, etc. 
con un tal Bernal Francés, maestro de hacer hilo de ballestas, al que se aludió anteriormente, que debió tener reconocimiento por dicha especialización en la fabricación de las ballestas, que no todos los ballesteros lograrían tener.

Lo mismo sucedería con los aprendizajes de la astería y adarguería, en los que se cumplirían todas las cláusulas recogidas en los contratos de aprendizaje realizados ante escribanos públicos y testigos, porque debían hacer el examen correspondiente para obtener la cualificación de maestro del oficio, que le permitía abrir taller o tienda, y para lograrlo, el aprendizaje era lógicamente imprescindible. La familia pudo ser un gran aporte en la enseñanza laboral pero indudablemente, no quedó solo en eso, pues los padres y jóvenes buscaron una mayor especialización con otros profesionales pese a ser del mismo oficio que los progenitores. Además se llega a comprobar, como lo ha visto Córdoba de la Llave, y también en los documentos notariales analizados, que se dio un movimiento migratorio en torno al trabajo $^{45}$, ya desde el aprendizaje como la documentación ha mostrado. Porque entre otras vicisitudes, también se buscaría el lugar y la persona idónea por su prestigio y buen hacer, con quién aprender el oficio en cuestión, y especialmente cuando de espadas y armaduras se trataba, y aunque ya conocemos ciudades como Toledo de gran prestigio en este campo, Córdoba también debió tener un cierto reconocimiento a tenor de los contratos de aprendizaje y aprendices foráneos recibidos.

\section{LUGARES DE RESIDENCIA}

Los distintos oficios de la industria armamentística estuvieron presentes, principalmente, en las collaciones de San Nicolás de la Axerquía y San Pedro. La primera es la preferida por armeros y espaderos para residir y trabajar, al tratarse de una zona muy comercial. La existencia de mesones en la calle y plaza del Potro -un tramo de esta calle recibió el nombre de calle de las Armas, donde los armeros residían según el padrón de 1509-, el discurrir de los viajeros y comerciantes que en ellos se alojaban, y la calle de la Feria, con su gran actividad y las dos ferias anuales que en ella se celebraban, harían que la demanda aumentara para estos profesionales. Así mismo, en dichos mesones se ubicaban las boticas, donde se ejercía la prostitución, que la convertían en una zona muy frecuentada. En ocasiones, incluso estos profesionales sirvieron como testigos en los documentos que realizaban dichos viajeros. Es el caso del espadero Luís López, hijo de Alfonso Rodríguez - que aun figuraba en el padrón de 1509, residiendo en la calle del Potro-, que lo hizo en el testamento de Diego Alfons, hijo de Alfonso Castellano, que había enfermado durante su estancia en el mesón de Miguel Romero, que se dice mesón del Mármol, donde actuó de albaceas dicho mesonero ${ }^{46}$.

La collación de San Nicolás de la Axerquía es la principal como lugar de residencia y trabajo de los asteros, es decir, también concentración de ellos en esta

45. Córdoba de la Llave 1984, p. 49.

46. AHPCO, PN 13666P (Escribanía 18), ff. 647r-v, 1487-03-11. 
collación. Así pues dicha collación era la armamentística por excelencia. En cuanto a los ballesteros, cuchilleros y vaineros, fue la collación de San Pedro la que acogió a dichos profesionales, que se concentraron en la calle de la Feria desde el pilar $^{47}$, es decir, la parte perteneciente a la misma. Los cuchilleros y vaineros se posicionaron en el tramo de la calle que recibió, por su concentración, el calificativo de entre los cuchilleros.

Los adargueros, residieron preferentemente en la calle de la Sillería, de la collación de San Nicolás de la Axerquía, como indican tanto los Protocolos Notariales como el padrón de 1509. Otro de los lugares donde también residieron adargueros fue en la calle de la Feria de la misma collación, en el Corral de los Correeros, y ello por la relación que tuvieron con correeros y miembros de la rama del cuero, como con los silleros en el anterior caso de la Sillería.

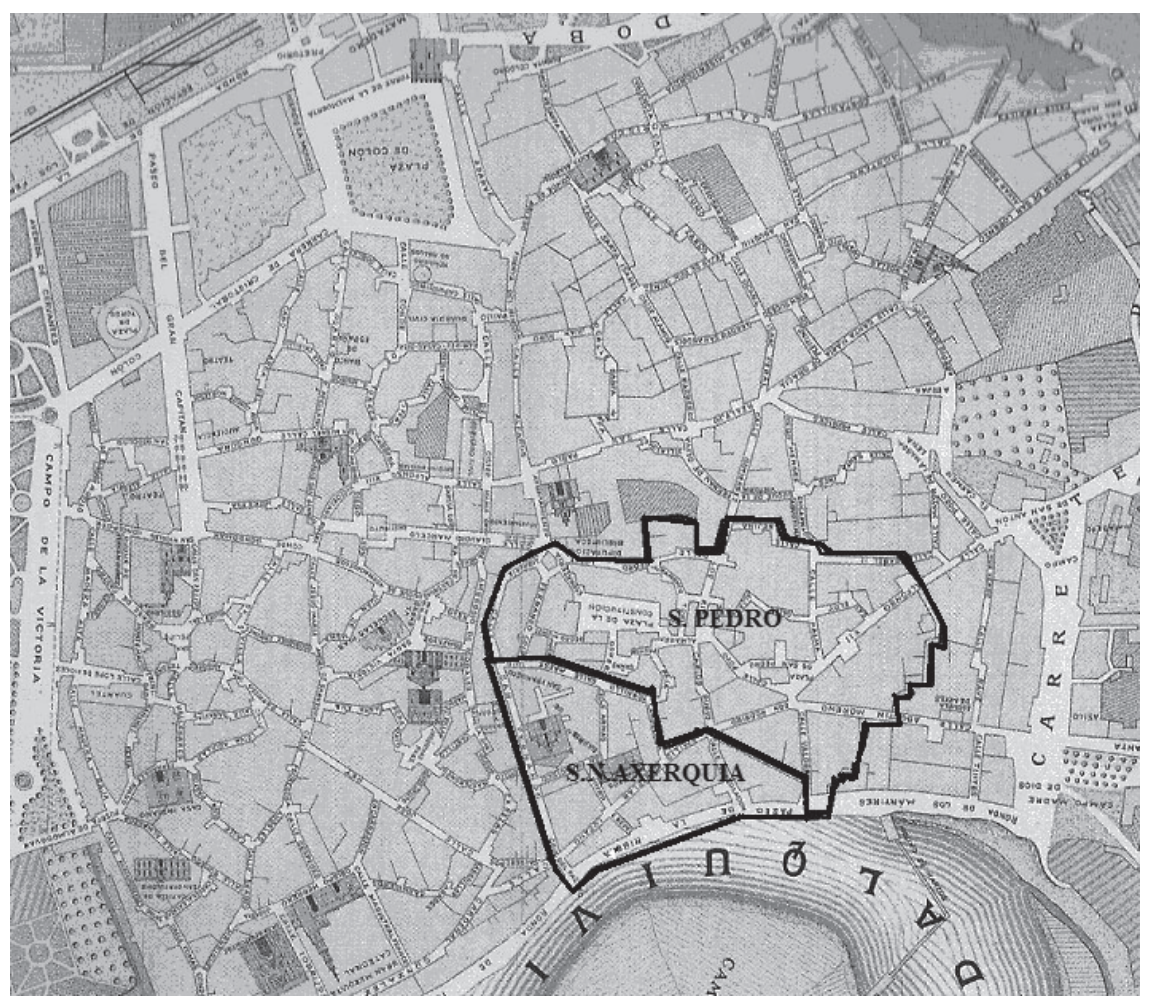

Collaciones de S. Nicolás de la Axerquía y San Pedro delimitadas sobre el Plano de Córdoba de 1910. Editado por Córdoba Artística y Útil. Del Prontuario del Viajero, por Alejandro Guichot.

47. Se refiere al pilar de agua que había junto al convento de San Francisco o de San Pedro el Real, hacia los Marmolejos, ya que la otra parte de la calle pertenecía a la collación de San Nicolás de la Axerquía. 
En resumen, las dos collaciones de San Nicolás de la Axerquía -armeros, espaderos, asteros y adargueros-y de San Pedro -ballesteros, cuchilleros y vainerosfueron principalmente los lugares de residencia y trabajo de los profesionales del armamento, con concentración entre la calle de la Feria y la calle y plaza del Potro. Sigue por tanto la incidencia de ambas ramas en dichas collaciones, pues respecto a la del metal, las prioritarias en Córdoba fueron las de San Pedro, 42,9\% de los profesionales en ella, y la de San Nicolás de la Axerquía, con casi la mitad de los anteriores (20,3\%), y en esta última, la presencia de los trabajadores del armamento tuvo una gran influencia en dicho porcentaje. En cambio, la principal collación respecto a la rama del cuero fue San Nicolás de la Axerquía (43\%), pero aquí la incidencia mayor fue la de los curtidores por la presencia en ella de las tenerías, ya que esta rama solo participó como complemento en la industria del armamento.

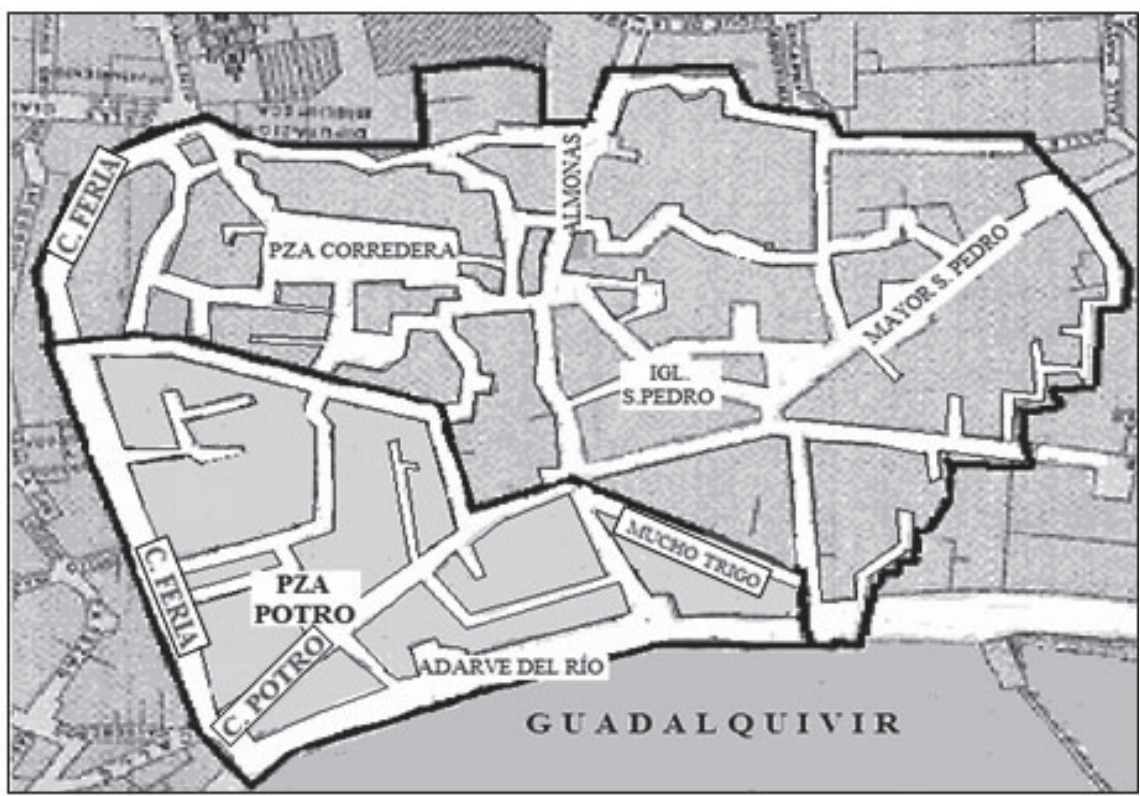

Concentración de los oficios del armamento: Calle de la Feria. Calle del Potro. Plaza del Potro.

\section{RELACIONES FAMILIARES}

En la época, las profesiones de los padres solían pasar a los hijos y así durante generaciones, convirtiéndose los talleres familiares en una constante en las ciudades, villas y lugares durante la Edad Media, como sucedió con los profesionales del armamento. Talleres que podían estar en las mismas casas de residencia. Por ello cuando se analiza la documentación, tanto notarial como los padrones que puedan existir, y aunque no sucediera en todos los casos, se intuye esta doble fun- 
cionalidad, sobre todo cuando de las cuatro collaciones más comerciales y artesanales de la ciudad se trataba: San Andrés, San Pedro, Santa María y San Nicolás de la Axerquía. Y en esos talleres o tiendas, aparte de la profesionalidad de los hijos que puedan participar, el papel de la mujer era esencial, con su trabajo y cooperación en muchas ocasiones, junto a los maridos. En lo tocante a las hijas era más difícil su participación, sesgada hacia unas determinadas profesiones consideradas femeninas y, en cambio, cuando contraen matrimonio, prestan apoyo al marido en cualquier tipo de oficio sin dicha discriminación, aunque en estos casos no consta oficialmente y solo se conocen particularmente por determinada documentación, como los testamentos. Pero respecto a los hijos, seguidores de los oficios de los padres, y en el ámbito de nuestro estudio del armamento, hay ejemplos que informan al respecto. Por la documentación notarial, existe constancia de una familia, ya anteriormente citada, que realizaba, solos o en compañía, contratos de aprendizaje, constituida por armeros, el padre, Juan Martínez, el hijo, Pedro Martínez y otro armero, Alfonso Martínez, que posiblemente pertenezca también a la misma familia, así como uno de los hijos, Gonzalo Martínez, que ejercía un oficio afín, hojero -forjaba las hojas de las espadas-, todos residentes en la collación de San Nicolás de la Axerquía ${ }^{48}$.

Así el armero Juan Martínez, aparte de sus hijos trabajando en la industria familiar, tenía a tres aprendices y, como criados, a dos hojeros, es decir, como mínimo reunía en su taller a ocho personas trabajando. Se desconoce si tuvo esclavos, algo que también era habitual entre los artesanos. Este tipo de talleres familiares podría ser frecuente entre los artesanos, especialmente entre los maestros que tuvieran más demanda, a lo que cabría agregar, como sucedió en muchas ocasiones, la participación de las esposas. Es el tipo de empresa familiar medieval, que contrataba a un pequeño grupo de trabajadores asalariados que podían figurar, en ocasiones como aprendices o criados, aunque encubrían a oficiales del oficio. Lo que también pudo llevar a conflictividades entre el maestro y los trabajadores, por las reclamaciones de éstos ante la falta de garantías para su trabajo. Queda comprobado que estos hechos se dieron en bastantes ocasiones, y los contratos de aprendizaje lo dejan ver a poco que se indague en este terreno.

A continuación se relacionan los armeros encontrados en el Archivo Histórico Provincial de Córdoba, Protocolos Notariales, agrupando los pertenecientes a la misma familia, y las fechas de los documentos.

48. Sin olvidar que los gremios mostraron una clara predilección por los hijos o familiares de los maestros de los oficios, pues las tasas fueron menores para éstos que para aquellos que no tenían a progenitores dentro, y otros matices que les beneficiaban. Córdoba de la Llave 2017, pp. 223-224, expone cómo en las Ordenanzas de sederos de Córdoba de 1529, a los hijos de los maestros no se les pedía abono de derecho alguno para ser examinados, y si los aprendices estaban casados con hijas de maestros, podían presentarse al examen en tres años, en lugar de los cinco exigidos. Este autor lo ponía en relación con el hecho de que las familias suponían "un espacio de asistencia intergeneracional", al no haberla a cargo de las instituciones públicas y eran los gremios y cofradías quienes llevaron estas cuestiones asistenciales a fin de ayudar a sus agremiados y cofrades, y la familia se convertía en la máxima apoyatura por encima de éstos. 


\begin{tabular}{|c|c|c|}
\hline Año & Nombre & Otros datos \\
\hline 1460 & Alfonso Sánchez & S. Andrés. Hijo de Lope Alfonso. \\
\hline 1460 & Antón Rodríguez & \\
\hline 1460 & Alonso Rodríguez & \\
\hline 1460 & Juan Rodríguez & Hijo del anterior, Alonso Rodríguez. \\
\hline 1464 & Alfonso Rodríguez, el Mozo & $\begin{array}{l}\text { En } 1487 \text { residía en S. Andrés. También hijo de } \\
\text { Alonso Rodríguez y hermano del anterior. }\end{array}$ \\
\hline 1460 & Juan Martínez & $\begin{array}{l}\text { S. N. Axerquía. Con él colaboraba su hijo Gonza- } \\
\text { lo Martínez, que era hojero. }\end{array}$ \\
\hline 1486 & Pedro Martínez & S. N. Axerquía. Hijo del anterior. \\
\hline 1489 & Alfonso Martínez & S. N. Axerquía. Posible hijo del primero. \\
\hline 1461 & Fernando Alfonso de Saavedra & S. N. Axerquía. \\
\hline 1461 & Antón & S. Andrés. Hijo de Juan de Córdoba \\
\hline 1464 & Juan García & \\
\hline 1464 & Sebastián Ruiz & \\
\hline 1464 & Luís & Hijo del anterior \\
\hline 1473 & Diego Alonso & En 1495 estaba fallecido. \\
\hline 1473 & Juan Rodríguez & $\begin{array}{l}\text { S. Andrés. Hijo del anterior. Sigue actuando en } \\
1495 .\end{array}$ \\
\hline 1473 & Martín Sánchez & \\
\hline 1474 & Antón Ruiz & S. N. Axerquía. Hijo de Antón Díaz. \\
\hline 1477 & Gonzalo de Úbeda & Hijo de Gil Gómez. \\
\hline 1480 & Lope de Buegnas & \\
\hline 1482 & Juan Alfonso & S. N. Axerquía. Hijo de Garci Fernández. \\
\hline 1483 & Alvar Fernández & S. Andrés. \\
\hline 1487 & Alfonso Fernández & S. Pedro. \\
\hline 1489 & Juan Alfonso & S. N. Axerquía. Hijo de Juan Alfonso. \\
\hline 1494 & Alonso Pérez & \\
\hline 1495 & Antón Ruiz & S. Andrés. Hijo de Fernando Rodríguez. \\
\hline 1495 & Fernando & Hijo del anterior. \\
\hline
\end{tabular}

Ahora se expone la relación de los armeros encontrados en el Padrón de 1509

\begin{tabular}{|l|l|l|}
\hline 1509 & Martín de Aragón & $\begin{array}{l}\text { S. N. Axerquía, calle Armas. Entendía en corazas, armas, } \\
\text { mallas y bastida. En 1512 solicitó al cabildo municipal } \\
\text { unas Ordenanzas de Armeros. }\end{array}$ \\
\hline 1509 & Pedro Fernández & S. N. Axerquía, calle Armas. \\
\hline 1509 & Pedro Gómez & S. N. Axerquía, calle Armas. \\
\hline 1509 & Juan Rodríguez* & $\begin{array}{l}\text { S. Andrés, barrera de las Marranas y es a la vez ganadero } \\
\text { y caballero de premia. }\end{array}$ \\
\hline
\end{tabular}

* Con anterioridad a 1509 había armeros residentes en la collación de San Pedro, según Protocolos Notariales, no obstante en el padrón de dicha fecha no se citan en dicha collación. En San Andrés residía el armero Juan Rodríguez, en la barrera de las Marranas que, según este padrón, se situaba entre la calle de los Cidros (actualmente conserva el mismo nombre) y la de Pedro de Angulo (la casa de los Angulo estaba en el entorno de la plaza de San Andrés), y era a la vez de armero, señor de ganado 
o ganadero, que llegó a obtener el privilegio, merced a su posición económica, de la caballería de premia. La documentación notarial informa que residía en San Andrés un armero del mismo nombre, Juan Rodríguez, hijo del también armero Diego Alonso, que actuaban ambos en 1473 y cuyo padre estaba ya fallecido en 1495, mientras el hijo actuaba todavía en dicha fecha. Podría tratarse del mismo Juan Rodríguez que figura en el padrón de 1509 o tal vez de un hijo suyo del mismo nombre y también armero, pues los armeros solían transmitir la profesión a los hijos. Indudablemente el que figura en el padrón de 1509 supo invertir sus ganancias en una actividad muy productiva en la época como era la ganadería, especialmente la tenencia de ganado ovino merino, por la venta de sus lanas a la industria textil, la principal en el bajomedievo, y actividad en la que invirtieron la nobleza y las clases enriquecidas provenientes de la clase pechera y el calificativo de señor de ganado que se otorgaba implicaba ser de los principales ganaderos ${ }^{49}$. Todo ello hizo que este armero alcanzase una posición económica y social que le llevó a dicha obtención de la caballería de premia con la cual se incluía en una categoría prenobiliaria que podía facilitarle el ascenso social, y librarle del pago de determinados impuestos o cargas fiscales, algo muy apetecible igualmente.

Los armeros localizados en las Ordenanzas de 1512 son los siguientes.

\begin{tabular}{|c|l|l|}
\hline 1512 & Luís Gutiérrez & \\
\hline 1512 & Pedro Fernández de Alcántara & \\
\hline 1512 & Desconocido & $\begin{array}{l}\text { Se citaba como "oficial en las Tendillas de Cala- } \\
\text { trava". }\end{array}$ \\
\hline 1512 & Pedro Gómez & Citado en el padrón de 1509. \\
\hline 1512 & Martín de Aragón & Citado en el padrón de 1509. \\
\hline
\end{tabular}

Lo mismo sucedía con los espaderos, donde el oficio podía pasar de padres a hijos, como la familia compuesta por Diego Alfonso, padre espadero, y el hijo Juan Rodríguez de Xerez, éste actuaba en la década de los 90 del siglo XV y residía en la collación de San Andrés. No es fácil seguir el rastro familiar en la documentación notarial, pues los escribanos públicos no siempre facilitaban las profesiones de los progenitores de los titulares de los documentos. Pensadores anteriores a esta época ya incidían en esta cuestión, como Ramón Llull exponía: la mejor riqueza que un padre podía dejar a su hijo era la enseñanza de un oficio y en sus escritos recomendaba a los jóvenes, de manera explícita, el aprendizaje de un oficio artesanal ${ }^{50}$.

49. Edwards 2001, pp. 157 y 173-175. Córdoba fue "un importante centro de recogida y venta de lana de todos los tipos de rebaños merinos", y donde los mercaderes burgaleses tuvieron contactos personalmente o por medio de agentes o intermediarios, y tras la fundación del "consulado" en Burgos, en 1494, varios priores y cónsules comerciaron con Córdoba, incluso este autor dice que los mercaderes burgaleses tuvieron reconocida su importancia para la economía local por el concejo cordobés, debido al gran número de productores de lana que había. Igualmente el autor alude al grupo mercantil establecido en Valladolid a mediados del siglo XV, que entre los 150 comerciantes que lo formaban había mercaderes de paños, peleteros, joyeros, plateros, especieros, cambistas y dos destacados armeros, lo que pone en evidencia la posición socioeconómica de este oficio.

50. Córdoba de la Llave 2016, p. 97. Porque Llull concede a las artes mecánicas un valor importante hasta el punto, incluso, de aconsejar el aprendizaje de las mismas a los hijos de los ricos, ya que para él no son viles como la nobleza consideraba, sino un recurso para el sostenimiento y la independencia. Pero respecto a las mujeres y su educación, silencio, pese a tener una hija y, en cambio, a su hijo le dedica "La Doctrina pueril" o manual escolar, y continúa con el primer libro de "Blanquerna", donde expone la educación y formación por la que podía discurrir la vida de su hijo, y así seguía la visión de 
Los espaderos encontrados en los Protocolos Notariales son:

\begin{tabular}{|c|l|l|}
\hline Año & \multicolumn{1}{|c|}{ Nombre } & \multicolumn{1}{c|}{ Otros datos } \\
\hline 1473 & Andrés Fernández & \\
\hline 1474 & Diego Alfonso de Clavijo & \\
\hline 1486 & Antón Muñiz & S. N. de la Axerquía \\
\hline $1486-87$ & Antón Núñez & S. N. de la Axerquía \\
\hline 1487 & Luís López* & \\
\hline 1489 & Luís Fernández & \\
\hline 1494 & Benito Fernández & S. N. de la Axerquía \\
\hline 1494 & Juan Garrido & S. N. de la Axerquía \\
\hline 1495 & Diego López & \\
\hline 1497 & Juan Rodríguez de Xerez & San Andrés. Padre Diego Alfonso, espadero. \\
\hline 1498 & Diego de Prado & \\
\hline
\end{tabular}

Relación de espaderos encontrados en el padrón de 1509.

\begin{tabular}{|l|l|l|}
\hline \multicolumn{1}{|c|}{ Nombre } & \multicolumn{1}{c|}{ Collación } & \multicolumn{1}{c|}{ Calle } \\
\hline Luís López* & S. N. Axerquía & Del Potro (actual Lucano) \\
\hline Luís de Carrera & S. N. Axerquía & Del Potro \\
\hline Francisco García & S. N. Axerquía & Plazuela de la Caridad (plaza del Potro) \\
\hline Juan López & S. N. Axerquía & Plazuela de la Caridad \\
\hline Pedro Fernández & San Andrés & Mayor hacia San Pablo \\
\hline Juan de Cea & San Andrés & Mayor hacia San Pablo \\
\hline Juan Catalán & San Pedro & Odrería (actual Sánchez Peña) \\
\hline Juan López Chaparro & San Pedro & Del Baño (actual Carlos Rubio) \\
\hline
\end{tabular}

* Posiblemente se trate del mismo individuo.

Los asteros, otros profesionales del armamento muy importantes, estaban relacionados con el mundo comercial vasco, incluso participando profesionales vascos en el espacio artesanal cordobés del oficio. En la astería, igualmente participaron por separado o conjuntamente miembros de una misma familia, formada por el padre Diego Sánchez y sus hijos Rodrigo, que era también mercader, y Juan de Córdoba, comerciando estos últimos conjuntamente "como hombres que compran y venden sin licencia del dicho su padre" ${ }^{51}$, y la otra conformada por el padre astero Alfonso García y su hijo Alfonso, también astero.

los hombres de su época, donde el varón era exclusivamente el destinatario de la atención educativa. Jular 2003, pp. 109-110. Todo esto también formaría parte del mundo del aprendizaje laboral y el papel dado a los hombres y las mujeres visto anteriormente. Es la valoración del trabajo en la época, por un autor que supo ver más allá de la elite social, lo que éste suponía para el funcionamiento de la sociedad, aunque apartaba a la mitad de la misma, las mujeres, del trabajo regulado, no de la realidad vital.

51. AHPCO, PN 13666P (Escribanía 18), f. 807r, 1487-09-14. 
No era extraño unir al oficio de astero el de mercader o comerciante. Y la misma relación había entre los de origen vasco que venían a Córdoba a trabajar y comerciar y en sus familias se distribuían ambos oficios.

A continuación, los asteros encontrados en los Protocolos Notariales.

\begin{tabular}{|c|l|l|}
\hline Año & \multicolumn{1}{|c|}{ Nombre } & \multicolumn{1}{c|}{ Otros datos } \\
\hline 1460 & Diego Sánchez & S. N. Axerquía. \\
\hline 1461 & Juan Martínez & Vizcaíno. S. N. Axerquía. \\
\hline 1473 & (Sin nombre) & $\begin{array}{l}\text { Hijo de Juan García de Gahete. S. N. } \\
\text { Axerquía. }\end{array}$ \\
\hline 1473 & Alfonso García & Santa María. \\
\hline 1473 & Juan Sánchez & San Pedro. \\
\hline 1483 & Antón Rodríguez & S. N. Axerquía. \\
\hline 1483 & Perucho & Vizcaíno. S. N. Axerquía. \\
\hline 1483 & Tomás González de Torquemada & S. N. Axerquía. \\
\hline 1487 & Alfonso & $\begin{array}{l}\text { Hijo del astero Alfonso García. S. N. } \\
\text { Axerquía. }\end{array}$ \\
\hline 1487 & Diego Sánchez & Santa María. \\
\hline 1487 & Rodrigo & Hijo del anterior y mercader. Santa María. \\
\hline 1489 & Diego Rodríguez & S. N. Axerquía. \\
\hline
\end{tabular}

En las seis collaciones conservadas del padrón de 1509, incluyendo la de San Nicolás de la Axerquía - donde los asteros tuvieron una fuerte impronta-, no se cita a ningún astero, aunque hay que hacer la salvedad de que una parte de los empadronados no tiene indicada su profesión.

Otros artesanos de esta industria son los ballesteros, que siguieron la misma pauta en cuanto a la transmisión del oficio, aunque no siempre es fácil encontrar documentos que lo ratifiquen.

A continuación, los encontrados en la documentación de Protocolos Notariales:

\begin{tabular}{|c|l|l|l|}
\hline Año & \multicolumn{1}{|c|}{ Nombre } & \multicolumn{1}{c|}{ Collación } & \multicolumn{1}{c|}{ Padre } \\
\hline 1473 & Juan Rodríguez & & \\
\hline 1480 & $\begin{array}{l}\text { Miguel Sánchez de Portillo } \\
\text { (maestro ballestero) }\end{array}$ & San Pedro & Pedro Sánchez \\
\hline 1483 & Luis González & San Pedro & Diego González \\
\hline 1486 & Alfonso Martínez & San Lorenzo & Alfonso Martínez \\
\hline 1494 & Bartolomé de Villaseca & San Pedro & Sánchez de Villaseca \\
\hline
\end{tabular}

Y así mismo los localizados en el padrón de 1509:

\begin{tabular}{|l|l|l|}
\hline \multicolumn{1}{|c|}{ Nombre } & \multicolumn{1}{c|}{ Collación } & \multicolumn{1}{c|}{ Calle } \\
\hline Francisco Gutiérrez & San Miguel & Que va al Adarve \\
\hline Pedro Ruiz & S. N. Axerquía & Feria \\
\hline Francisco Rodríguez & San Pedro & Feria desde el pilar \\
\hline maestre Luís & San Pedro & Feria desde el pilar \\
\hline
\end{tabular}


En los cuchilleros, aparte del oficio propio que los hijos tomaban de los padres, existió una interrelación con el oficio de vainero, perteneciente a la rama del cuero, y ya se ha visto que algunos de los cuchilleros lo aprendieron para unir ambas actividades, pero se observa que, igualmente, incidieron ambos en la misma familia, como es el caso del cuchillero Antón Rodríguez, que era hijo del vainero Juan Sánchez. De hecho, la búsqueda de residir en la misma calle de la Feria entre los cuchilleros, de la collación de San Pedro, de ambos oficiales, cuchilleros y vaineros, derivaba de dichas circunstancias familiares y de complementariedad de ambos trabajos, por lo cual van unidos en este apartado de la cuchillería.

A continuación, los cuchilleros encontrados en los Protocolos Notariales.

\begin{tabular}{|c|c|c|c|}
\hline Año & Nombre & Collación & Padre cuchillero o rama metal \\
\hline 1460 & Gómez & & \\
\hline 1460 & Alfonso Martínez & S. Lorenzo & \\
\hline 1460 & Benito González & S. Pedro & \\
\hline 1460 & Diego Alfonso & S. Pedro & \\
\hline 1460 & Juan González & S. Pedro & \\
\hline 1460 & Martín Rodríguez & S. Pedro & \\
\hline 1461 & Fernando López & & \\
\hline 1461 & Juan de Valladolid & Estante & \\
\hline 1461 & Alfonso & S. Pedro & Fernando López, cuchillero \\
\hline 1461 & Alfonso de Córdoba & S. Pedro & \\
\hline 1461 & Juan Martínez & S. Pedro & \\
\hline 1461 & Alfonso Díaz & S. Pedro & Juan Martínez, cuchillero \\
\hline 1465 & Francisco & S. Pedro & Diego Alfonso, cuchillero \\
\hline 1470 & Pedro (hijo de Antón Ruiz) & & \\
\hline 1473 & Gil Álvarez & S. Pedro & \\
\hline 1473 & Juan Rodríguez de Priego & S. Pedro & \\
\hline 1474 & Alfonso García & & \\
\hline 1474 & Antón Ruiz & & \\
\hline 1474 & Juan de Baena & & \\
\hline 1475 & Diego de Villafranca & & \\
\hline 1475 & Juan de Castro del Río & & \\
\hline 1475 & Pedro de Cazorla & & \\
\hline 1475 & Alfonso Rodríguez & S. Pedro & Diego, cuchillero \\
\hline 1479 & Juan Alfonso Maldonado & & \\
\hline 1480 & Juan Delgado & S. Pedro & \\
\hline 1482 & Pedro García & & \\
\hline 1482 & Alfonso (también vainero) & S. Pedro & Juan Sánchez, rama metal \\
\hline 1482 & Antón Rodríguez & S. Pedro & Juan Sánchez, rama metal y vainero \\
\hline 1482 & Juan de Soria & S. Pedro & \\
\hline 1482 & Lope Ruiz & S. Pedro & \\
\hline 1483 & Diego Fernández & S. Pedro & \\
\hline 1483 & Gonzalo García & S. Pedro & \\
\hline
\end{tabular}




\begin{tabular}{|c|l|l|l|}
\hline Año & \multicolumn{1}{|c|}{ Nombre } & Collación & Padre cuchillero o rama metal \\
\hline 1486 & Bartolomé de Segura & & \\
\hline 1486 & Francisco de Pineda & S. Juan & \\
\hline 1487 & Pedro Ruiz & S. Lorenzo & \\
\hline 1487 & Alfonso Rodríguez del Río & S. Pedro & \\
\hline 1487 & Antón de Cea & S. Pedro & \\
\hline 1489 & Alfonso del Río & & \\
\hline 1491 & Diego de Madrid & S. Pedro & \\
\hline 1493 & Fernando de Lugo (gallego) & Estante & \\
\hline 1493 & Juan de Córdoba & S. Pedro & \\
\hline
\end{tabular}

Los cuchilleros encontrados en el padrón de 1509 son:

\begin{tabular}{|l|l|l|}
\hline \multicolumn{1}{|c|}{ Nombre } & \multicolumn{1}{c|}{ Collación } & \multicolumn{1}{c|}{ Calle } \\
\hline Juan de Córdoba & S. Andrés & Mayor hacia S. Pablo \\
\hline Juan Ruiz & S. Pedro & Feria desde el pilar \\
\hline Orvaneja & S. Pedro & Feria desde el pilar \\
\hline Sebastián Pérez & S. Pedro & Feria desde el pilar \\
\hline Bartolomé Ruiz & S. Pedro & Feria desde el pilar \\
\hline Juan Gaciret (hidalgo) & S. Pedro & Feria desde el pilar \\
\hline Francisco del Varco & S. Pedro & Feria desde el pilar \\
\hline Alonso de Torres & S. Pedro & Feria desde el pilar \\
\hline Antón de Baena & S. Pedro & Feria desde el pilar \\
\hline Pedro Sánchez & S. Pedro & Feria desde el pilar \\
\hline Pedro Hernández & S. Pedro & Feria desde el pilar \\
\hline Juan Rodríguez & S. Pedro & Feria desde el pilar \\
\hline Diego López & S. Pedro & Feria desde el Pilar \\
\hline
\end{tabular}

Vaineros encontrados en los protocolos notariales.

\begin{tabular}{|c|l|l|l|}
\hline Año & \multicolumn{1}{|c|}{ Nombre } & Collación & Padre vainero \\
\hline 1461 & Pedro Martínez & & \\
\hline 1461 & Fernando Portugués & S. Pedro & \\
\hline 1461 & Juan Sánchez & S. Pedro & \\
\hline 1461 & Sancho Gómez & S. Pedro & \\
\hline 1474 & Antón Sánchez & & \\
\hline 1474 & Antón Rodríguez & S. Andrés & Juan Sánchez, vainero \\
\hline 1482 & Gabriel de la Torre & S. Pedro & \\
\hline 1483 & Diego González & & \\
\hline 1483 & Pedro Fernández & & \\
\hline 1483 & Benito Ruiz & S. Pedro & Pedro Ruiz, vainero \\
\hline 1486 & Andrés González & & \\
\hline 1486 & Juan Rodríguez & & \\
\hline 1486 & Ruy Fernández de Pineda & S. Pedro & \\
\hline
\end{tabular}


Los vaineros encontrados en el padrón de 1509 son:

\begin{tabular}{|l|l|l|}
\hline \multicolumn{1}{|c|}{ Nombre } & \multicolumn{1}{c|}{ Collación } & \multicolumn{1}{c|}{ Calle } \\
\hline Juan del Águila & S. Pedro & Feria desde el pilar \\
\hline Francisco Sánchez & S. Pedro & Feria desde el pilar \\
\hline Alonso Hernández Beteta & S. Pedro & Feria desde el pilar \\
\hline Juan de Segura & S. Pedro & Feria desde el pilar \\
\hline
\end{tabular}

Otro elemento del armamento, el escudo, servía de protección y también la materia prima para su elaboración provenía de la rama del cuero, como en el caso de las vainas. Entre los adargueros o fabricantes de adargas localizados en los Protocolos Notariales, había familias dedicadas al oficio, como Alfonso Martínez y su hijo del mismo nombre, que residían en la collación de San Nicolás de la Axerquía, y actuaban en la década de los ochenta del siglo XV. En el padrón de 1509 hay un solo adarguero, Juan Martínez, que residía en la calle de la Sillería de la mencionada collación, pudo ser familiar de los anteriores Alfonso Martínez, padre e hijo, ya que era habitual pasar el oficio a lo largo de generaciones.

Los adargueros encontrados en los protocolos notariales son:

\begin{tabular}{|c|l|l|l|}
\hline Año & \multicolumn{1}{|c|}{ Nombre } & \multicolumn{1}{c|}{ Collación } & \multicolumn{1}{c|}{ Otros datos } \\
\hline 1482 & Fernando & S. N. Axerquía & $\begin{array}{l}\text { Calle de la Feria en el Corral de los } \\
\text { Correeros }\end{array}$ \\
\hline 1484 & Alfonso Martínez & S. N. Axerquía & \\
\hline 1484 & Alfonso Martínez & S. N. Axerquía & Hijo del anterior \\
\hline 1484 & Miguel Ruiz & S. N. Axerquía & $\begin{array}{l}\text { Calle Sillería. Padre, Antón Ruiz, } \\
\text { correero. }\end{array}$ \\
\hline
\end{tabular}

\section{RELACIONES COMERCIALES}

Todos los profesionales del armamento, como otros artesanos, podían vender sus productos directamente en sus talleres o tiendas, y a través de comerciantes o mercaderes, así como la compra de las materias primas para realizar sus labores, con lo que podían comprar igualmente a mercaderes foráneos como a cordobeses, y a su vez ellos mismos también podían actuar de comerciantes, al vender dichas materias primas a otros artesanos de la ciudad, aparte de su propio aprovisionamiento. Por ello las relaciones comerciales llegaron a formar parte de su propio trabajo y, específicamente, en esta especialidad donde el metal era la materia fundamental, y el hierro procedía mayoritariamente del país vasco, por lo que para estos profesionales fueron muy importantes las relaciones con los mercaderes vizcaínos, como se comprueba a través de la documentación de los Protocolos Notariales del Archivo Histórico Provincial de Córdoba, especialmente en una profesión, la de astero, encargados de fabricar las lanzas. Las hojas serían hechas en esta ciudad y los hierros o astas eran importados frecuentemente desde Vizca- 
ya, ya que abundaban las ventas de astas por mercaderes vizcaínos a los asteros cordobeses $^{52}$.

El fluir de la mercadería vasca a Córdoba llevó consigo la llegada y avecindamiento de los asteros vascos, con residencia fija o como estantes, laborando en este caso por un cierto tiempo como los mercaderes que figuraron de tal manera. Éstos también podían dejar factores encargados de las ventas y cobros, así como de las compras de distintos productos, fijando ellos, en ocasiones, su residencia en Sevilla o bien en su propia tierra. Fue un trasiego comercial hacia el sur, donde ciudades como Sevilla o Córdoba tenían una gran actividad artesanal y comercial, que precisaba de sus productos, especialmente el hierro vasco.

Los propios asteros vizcaínos fomentaban aún más dichas relaciones con mercaderes de su mismo origen, a los cuales les compraban ciertas mercaderías de astería o ciertas astas como se dice en algunas obligaciones de los Protocolos Notariales.

La industria de la astería estuvo en muchas ocasiones unida al negocio del mercadeo, ejerciendo ambas actividades conjuntamente o por separado entre distintos miembros familiares. Es el caso de la familia de asteros cordobeses formada por el padre Diego Sánchez, astero, y sus hijos Rodrigo, astero y mercader, y Juan de Córdoba. Estos últimos comerciaron conjuntamente como hombres que compran $y$ venden sin licencia del dicho su padre ${ }^{53}$. Igualmente sucedía en nuestra ciudad con ciertas familias vascas como Pedro de Lenis, vizcaíno, hijo del astero Pedro de Gorostiza, que estaba estante en Córdoba, y que ejerce como testigo en los negocios llevados a cabo por los mercaderes vascos, Pedro de Aristizábal, vecino de San Nicolás de la Axerquía, y Juan de Estenimbar, vecino de Lorrio ${ }^{54}$. Es más, los propios asteros actuaron como factores de mercaderes o encargados de las compras de mercadería en otras ciudades como Sevilla. Así lo hizo el astero Diego Sánchez - puede que se trate del anteriormente citado--, de la collación de San Nicolás de la Axerquía, que recibió poder especial del mercader Pedro Rodríguez, de San Pedro, a fin de que se obligase en cuantía de $40.000 \mathrm{mrs}$. en su nombre, en la compra de cualquier mercadería en Sevilla, comprometiéndose a pagarlos en los plazos que fijara el mencionado astero (el mismo astero fiaba con su propio dinero al mercader $)^{55}$. No extrañan dichas implicaciones y delegaciones comerciales, de las que hay muchos ejemplos en la documentación notarial ${ }^{56}$.

52. Córdoba de la Llave 1990, p. 269.

53. AHPCO, PN 13666P (Escribanía 18), f. 807r, 1487-09-14.

54. AHPCO, PN 13666P (Escribanía 18), f. 624v, 1487-02-08.

55. AHPCO, PN 14104P (Escribanía 14), f. 108v, 1460-12-s. d.

56. Como ejemplos, los siguientes documentos: En AHPCO, PN 13665P (Escribanía 18), cuad. 4, f. 14r, 1473-07-06, el astero Diego Sánchez, de San Nicolás de la Axerquía -puede ser el mismo aludido en el texto-, compra al mercader vizcaíno Pedro de Monjaras, mercaderías de astería por valor de 6.500 mrs.; en AHPCO, PN 13666P (Escribanía 18), f. 622v, 1487-02-06, el astero y mercader vizcaíno Pedro de Aristizábal, residente en San Nicolás de la Axerquía, compra astas al mercader vizcaíno, vecino de Lorrio, Pedro de Gascueta, por 8.350 mrs.; en AHPCO, PN 13666P (Escribanía 18), f. 624v, 1487-02-08, el anterior mercader y astero debe pagar a Juan de Estenimbar, mercader vizcaíno, vecino de Lorrio, 14.550 mrs. que le prestó su padre Pedro de Estenimbar. 
Se comprueba que hubo una nómina de mercaderes vizcaínos en la ciudad, tanto residentes como estantes, que junto a asteros del mismo origen conformaron un negocio lucrativo, sin olvidar que tenían una amplia clientela, no solo en los asteros, sino también en los cerrajeros, herradores y herreros a los que suministraron los materiales necesarios para sus labores.

Los asteros no solo mantuvieron relaciones comerciales con los mercaderes vascos, sino que abarcaban a mercaderes de otros lugares del país, como los vallisoletanos, llegando incluso a los préstamos monetarios, lo que da buena muestra de la confianza mutua ${ }^{57}$. Pero los mercaderes vizcaínos fueron los principales en este comercio, pues llegaron incluso a utilizar las casas-tienda de los asteros como lugares de almacenaje de sus artículos, previo pago de un alquiler, para que sus factores los pudiesen vender a diferentes compradores ${ }^{58}$

Otros profesionales liberales como los escribanos públicos formaron parte de las relaciones comerciales de los asteros, no solo como fedatarios de cualquier actividad sino como participantes en los negocios comerciales de éstos. Éste fue el caso del escribano Pedro Fernández de Ferrera, y sus relaciones con el astero Alfonso García, que le debía determinadas cuantías monetarias visibles a través de la documentación notarial ${ }^{59}$.

Los asteros fueron unos personajes importantes en el discurrir comercial de la ciudad. El astero Diego Rodríguez, residente en una casa-tienda de la collación de San Nicolás de la Axerquía, tenía relación comercial con el mercader vizcaíno Juan Pérez de Rezábal, estante en Córdoba en el año 1489, que le vendió cierto hierro, herraje y clavo, por 263.000 mrs. ${ }^{60}$ No solo compraba hierro para su profesión, sino también herraje y clavo que utilizaban los herradores, por lo que comerciaba a mayor escala que la derivada de su propio oficio. Casos iguales suceden con los cerrajeros, que comerciaban con mercaderes vizcaínos, como la familia Ruiz de Requena, con cuantías elevadas como la anteriormente citada. Todo ello deja ver la importancia y fluidez de las relaciones comerciales entre los mercaderes vascos y los profesionales cordobeses del metal, en su distribución de los metales por la ciudad. No hay que olvidar la variedad de las obras que se realizaban y la especialización en sus técnicas de dichos oficios, lo que convierte

57. AHPCO, PN 13666P (Escribanía 18), f. 750r, 1487-07-19. Alfonso, astero, hijo del también astero Alfonso García, vecino de la collación de San Nicolás de la Axerquía, mantenía relaciones comerciales con el mercader vallisoletano Antonio de Valladolid, como para que éste le prestara dinero.

58. AHPCO, PN 13666P (Escribanía 18), f. 348r, 1483-12-09. Pedro Martínez de Zabala, mercader vizcaíno, estante en Sevilla, dice que tiene en la casa-tienda de Perucho, astero vizcaíno, vecino de San Nicolás de la Axerquía, 300 docenas de ferrajes terciados, pagando un alquiler de 20 mrs. mensuales. Da poder a su sobrino Miguel de Vergara, para que pueda vender dicho ferraje al astero Antón Rodríguez, vecino de dicha collación, al precio de tres mrs. por cada docena que venda.

59. En AHPCO, PN 13665P (Escribanía 18), cuad. 4, f. 60r, 1473-10-01, Alfonso García, astero, hijo de Juan García de Gahete, vecino de San Nicolás de la Axerquía, debe pagar a Pedro Fernández de Ferrera, escribano, 24.600 mrs. En AHPCO, PN 13665P (Escribanía 18), cuad. 4, f. 60r, 1473-1001, el escribano Pedro Fernández de Ferrera, hace finiquito a Alfonso García, astero, de la cantidad de $37.480 \mathrm{mrs}$. que le debía. Indudablemente hubo relaciones comerciales, pero también el préstamo tuvo influencia en este mundo del comercio.

60. AHPCO, PN 13667P (Escribanía 18), f. 51v, 1489-02-11. 
a esta rama en una industria muy fuerte, visible en los hechos relatados respecto a los asteros y la participación procedente del país vasco, tanto en el oficio, que los atrajo a Córdoba por la situación de frontera que tenía en la Baja Edad Media, como a los mercaderes que traían el metal. Aunque una parte de dicho metal pudo proceder de los yacimientos mineros de Sierra Morena ${ }^{61}$, cobre o hierro, aunque indudablemente, el hierro procedía en su mayoría del país vasco. El interés de los asteros en invertir en este comercio era debido a la rentabilidad que les proporcionaba ya que según Córdoba de la Llave, el hierro que los mercaderes cordobeses compraban en Sevilla a los vizcaínos tenía un precio en torno a los $220 \mathrm{mrs}$. el quintal y lo vendían en Córdoba entre 400/450 mrs. ${ }^{62}$ La ganancia era evidente.

Los armeros, que solían trabajar en tiendas o talleres familiares, conjuntamente padres e hijos o en negocios comerciales, también formaron, en algunos casos, compañías mercantiles con otros individuos. Así lo hizo uno de los hijos de la familia de armeros Martínez, Pedro Martínez, vecino de San Nicolás de la Axerquía, que tenía formada compañía mercantil con otro individuo, Bartolomé Ruiz Merino, vecino de la collación de Santiago, compraban mercaderías a Diego de Orvaneja, vecino de San Nicolás de la Axerquía, por un importe de 20.360 mrs. ${ }^{63}$ Ésta podía ser una de las muchas compras que realizaron bien para el oficio de la armería o bien como comerciantes que podían abarcar a productos de muy diversa índole, y no solo del metal, ya que invertían en otras actividades con la finalidad de obtener mayores ingresos y rentas.

Otros armeros, que igualmente conformaron una familia, fueron Juan Rodríguez, hijo del armero Diego Alonso, y el armero del mismo nombre Juan Rodríguez, que figuraba en el padrón de 1509, que tanto podía ser el mismo citado primeramente en los Protocolos Notariales, o bien un hijo suyo del mismo nombre y también armero. Éste último supo invertir sus ganancias en una actividad como la ganadería, muy rentable en la época, especialmente ovina merina, por lo que pudo tener relaciones comerciales con mercaderes burgaleses, los principales compradores de lana a los señores de ganado o ganaderos cordobeses. Este calificativo implicaba ser de los principales ganaderos, como era éste el caso y de cuya posición económica se derivó el privilegio de la caballería de premia que recibió. J. Edwards, expuso cómo un grupo mercantil de Valladolid conformado por 150 comerciantes que actuaba a mediados del siglo XV, estaba compuesto, entre otros artesanos y comerciantes, por dos destacados armeros, reflejando la posición socioeconómica del oficio, que les había aupado a mantener y formar parte de compañías comerciales importantes ${ }^{64}$.

61. AHPCO, PN 13665P (Escribanía 18), cuad. 5, f. 23r, 1474-02-28. Hubo tiendas de ferrerías en la collación de San Andrés. Una de ellas recibió el nombre de "tienda y ferrería de Santa María”.

62. Córdoba de la Llave 1990, p. 227.

63. AHPCO, PN 13666P (Escribanía 18), f. 386v, 1486-02-09. Debían pagar dicha deuda en esta ciudad desde la fecha del documento hasta diez días después de Pascua Florida.

64. Edwards 2001, pp. 173-175. 
Así mismo los ballesteros mantuvieron relaciones tanto por su trabajo como comerciales, de crédito, etc., con vecinos de Toledo ${ }^{65}$. Como los asteros, los ballesteros igualmente tuvieron relaciones comerciales con vascos, por su necesidad del metal, y para ello, si hacía falta, recurrían al préstamo o a la formación de compañías ${ }^{66}$.

Los cuchilleros también mantuvieron relaciones con aquellos mercaderes que les podían proporcionar el hierro o el acero, que después iban a forjar para utilizar en puñales, navajas, cuchillos, tijeras, etc. Como hicieron los demás artesanos, buscaron comprar esclavos a diferentes mercaderes que se dedicaban a dicha venta, porque además de tener oficiales u obreros para trabajar en las fraguas elaborando hojas y cuchillas a cambio de un salario ${ }^{67}$, usaron con frecuencia a esclavos que podían trabajar con ellos una vez aprendido el oficio, además de dedicarlos a los trabajos más penosos como era el de la fragua. Un ejemplo fue el cuchillero Juan de Córdoba, hijo de Juan Rodríguez, que compró a Pedro González Gallego, portugués, vecino de Torres Vedres, término de Lisboa, un esclavo de color negro de nombre Juan, de 13 años y natural de Guinea, por $7.500 \mathrm{mrs} .^{68}$ Por la edad del esclavo, bien pudo ser comprado para enseñarle el oficio a fin de que trabajara junto a él, convirtiéndose de esta manera en una buena inversión, porque hay que decir que de esta mano de obra esclava se obtuvieron rendimientos económicos en el mundo laboral, evidenciado por la frecuencia de la tenencia de esclavos por

65. AHPCO, PN 13665P (Escribanía 18), cuad. 26, f. 39r, 1494-02-28. Bartolomé de Villaseca, ballestero, vecino de la collación de San Pedro, pagó a Alfonso de Salazar, vecino de Toledo, más de 40 reales de plata castellanos que le debía.

66. AHPCO, PN 13665P (Escribanía 18), cuad. 12, f. 7r, 1480-01-30. El maestro ballestero Miguel Sánchez de Portillo, vecino de la collación de San Pedro, recibió en préstamo de Pedro de Bilbao, vizcaíno, afinador de la Casa de la Moneda de Sevilla, 1.000 mrs. para comprar acero en Sevilla -posiblemente cuando fue a esta ciudad para comprar las materias necesarias para su oficio, pudo precisar dinero para la compra realizada-. El préstamo se hizo hacía dos años -curioso que después de dos años transcurridos del débito, se haga ahora la obligación ante escribano público, con la finalidad de poner un plazo ¿o fue simplemente apalabrado y ante el incumplimiento del ballestero o deudor, el acreedor se vio obligado a realizar el documento para la constancia y sanción correspondiente en caso de impago a la fecha fijada, que solía ser del doble de la cantidad prestada?

67. Córdoba de la Llave 1990, p. 266, nota 86. Donde consta el precio pagado por cada cuchilla a 14,5 mrs. en el año 1468. En este caso son cuchillas con sus cañivetes escotados.

68. AHPCO, PN 13669P (Escribanía 18), f. 359v, 1493-11-20. La trata de negros y su comercio estuvieron en manos de los portugueses, como en este documento se refleja, donde se indica el origen y lugar de procedencia del vendedor. Dicho portugués debió estar en Córdoba como estante aunque en el documento no se indica, o bien proceder de Sevilla donde figuraría como tal, pues a tenor de lo que Franco Silva refiere las tres ciudades portuguesas de Lisboa, Tavira y Lagos son las que tenían mayor número de mercaderes en Sevilla y otras ciudades. Franco Silva 1992, p. 55. Gloria Lora ha detectado la presencia de mercaderes portugueses en Córdoba, casi siempre de paso. Lora 1982, pp. 177-191. Otro ejemplo de tenencia de esclavos, fue la esclava Catalina, blanca, de 32 años y su hijo Miguel de 9, pero en esta ocasión huyeron de sus amos, el espadero Juan de Jaén y su esposa Elvira Fernández. Aunque se conoce que lo hicieron a las Alpujarras, se desconoce si fue por maltrato, por deseos de libertad o porque podían querer separarlos por venta. Páez García dice que los niños solían venderse con sus madres, por supervivencia de aquellos, pero dada la edad que ya entraba en una etapa que dicho autor señala como provechosa para comenzar en el trabajo, puede que les interesara venderlos por separado. Páez García 1994, p. 212. 
parte de los artesanos, aunque no en exceso numérico, pues solían tener uno o dos, pero la recurrencia reafirma dicho interés y rentabilidad.

La presencia en Córdoba de mercaderes portugueses dedicados a la venta de esclavos, normalmente como estantes o de paso, procedentes de Sevilla, se vería favorecida por el interés de los artesanos en la compra de dichos esclavos, pero también pudo favorecer la salida de sus productos elaborados a través de estos mismos mercaderes, como sucedía con otros comerciantes de distintas procedencias.

\section{LA ECONOMÍA DE LOS ARTESANOS DEL ARMAMENTO. EL NEGOCIO INMOBILIARIO}

Hasta aquí se han expuesto las siguientes inversiones de los artesanos del armamento: comerciales, a través de las relaciones mercantiles con otros comerciantes; de trabajo, por la formación de compañías con distintos artesanos; ganaderas y compra de esclavos. Ahora se abordan otros campos de inversión, como el inmobiliario, que podía ir desde la compra de la propia vivienda y del taller o tienda para desarrollar su trabajo, hasta otras casas, casas-tienda y tiendas, con la finalidad de tener un recurso del que poder extraer un beneficio económico mediante el alquiler o la propia venta posterior al elevar su precio. Pero no solo los alquileres daban rentabilidad a sus propietarios, sino que aquellos individuos que tenían alguna propiedad inmobiliaria en régimen de alquiler podían volver a realquilarlos. Un negocio muy rentable como se verá en algunos de los documentos notariales que se van a exponer.

Otras inversiones muy acordes con la sociedad del momento fueron las compras de tierras, viñedos, olivares, lagares, etc., y en un negocio rentable como era el ganadero, que requería de dehesas y pastizales.

Por tanto los artesanos del armamento invirtieron en el negocio inmobiliario cuando las ganancias obtenidas de su trabajo se lo permitían, lo cual les hacía afrontar la vida cotidiana con más tranquilidad.

Empezamos por aquellos profesionales que tenían casas como inversión, que a veces utilizaron como donaciones a sus hijos para mejorar sus vidas. Este es el caso del armero Juan Martínez y su esposa Marina Rodríguez, que donan a su hija beata ${ }^{69}$, Catalina Rodríguez, unas casas valoradas en 8.000 mrs., más bienes muebles y otras cosas valorados en $6.400 \mathrm{mrs}$. (total, $14.400 \mathrm{mrs}$.) de su herencia,

69. Las beatas no estaban acogidas a ningún monasterio ni orden religiosa, ya que vivían en sus propios domicilios. A lo sumo podían juntarse varias en una casa y, normalmente, alguna de ellas poseía la vivienda en propiedad, y pudieron tener otros bienes inmuebles más. Este era el caso de las tres hermanas Armenta, residentes en la collación de la Magdalena, que poseían, además de las casas de su residencia, otras casas, huertas, etc., y hasta llegaron a fundar una capellanía. Todo ello va a depender de la situación económica familiar, pues recibían por herencia o donación dichos bienes de los que después obtenían rentas por medio de los alquileres, como sustento económico, que las hacía más o menos independientes para ejercer su propia religiosidad y solidaridad, no siempre bien vista por las instituciones religiosas, ya que podían escapar a su control. Para ver más sobre este tema Miura 1988, 2017. 
con la finalidad de que pueda sostenerse. Estas casas, situadas en la calle Grajeda, tenían lindes con las casas de sus padres, que le dan permiso para entrar en ellas a tomar agua del pozo ${ }^{70}$.

Otro armero que podía pertenecer a dicha familia, como se aludió con anterioridad, Alfonso Martínez, muestra un ejemplo de subarriendo, además de reflejar las relaciones entre armeros, a través de un documento notarial donde dice que tenía unas casas en la calle Nueva de Consolación -con dos puertas a la calle-en la collación de San Nicolás de la Axerquía, alquiladas de Fernando de Priego, y las subarrendaba al armero Juan Alfonso, vecino de dicha collación, durante cuatro años y una renta anual de 1.500 mrs., con la condición de que las adobe y repare de las labores que fueren necesarias, pagando la renta a los herederos de dicho Fernando de Priego. En este caso no parece que en el subarriendo se aumentara la renta en beneficio del subarrendador, ya que se pagaba directamente a los propietarios, lo que sí es visible es que debían hacerse reparaciones en dichas casas a cargo del armero Juan Alfonso, el último que se hacía con el alquiler de ellas; quizás pudo ser ésta la causa del subarriendo que eximía al primer armero de realizarlas, reportándole dicho beneficio económico ${ }^{71}$.

La inversión en bienes inmuebles está presente en otro ejemplo: el armero Fernando Alfonso de Saavedra, de San Nicolás de la Axerquía, compra unas casas en la calle de las Siete Revueltas, en la barrera del Rastrero, en la collación de Santiago, por $8.500 \mathrm{mrs}^{72}$.

Estas adquisiciones pueden posteriormente ser puestas a la venta como hace el astero Alfonso García, presente en otras operaciones, que vende unas casas en la collación de San Lorenzo, que lindaban con otras también de su propiedad, por $10.000 \mathrm{mrs}^{73}$. Se comprueba cómo tenía distintas viviendas en otra collación diferente a la de su residencia, es decir, la inversión en este negocio es indudable.

En otras ocasiones son los propios profesionales los que alquilaban casas para residir, sobre todo en lugares que fueran interesantes para su oficio y difíciles de adquirir por compra por su elevado coste o porque sus propietarios no las venderían dada su rentabilidad en el alquiler y la fuerte demanda de ellas, tanto casas como tiendas o casas-tienda. Este fue el caso del astero Diego Rodríguez, que alquila unas casas con su corral en la collación de San Nicolás de la Axerquía, que estaban junto al monasterio de San Francisco, y cuya propietaria tenía también una casa-tienda junto a ellas. El mismo Diego Rodríguez, igualmente tenía alquilada de por vida una casa-tienda junto a la que alquilaba, lo que parece indicar

70. AHPCO, PN 14104P (Escribanía 14), ff. 39r-40v, 1464-07-07. En dicha calle, según el padrón de 1509, residían 26 vecinos, cinco de los cuales en casas individuales y el resto en seis casas de vecinos. Entre los profesionales, tres de ellos eran mercaderes, tres guarnicioneros, cinco agujeros, dos doradores, dos herradores, un frenero, un batihoja, un esmolador, un tejedor, un cardador, un pellejero, un trabajador y un arriero, así como varias viudas. En 1509 no figuraba ningún armero en ella, pues residían éstos en la calle Armas, donde además se encontraba el hospital de Consolación.

71. AHPCO, PN 13668P (Escribanía 18), f. 6r, 1489-01-06.

72. AHPCO, PN 14104P (Escribanía 14), ff. 1v-2r, 1461-11-10. Casas compradas al labrador Juan Alfonso de Valdés, el Mozo, vecino de la collación de San Lorenzo.

73. AHPCO, PN 13665P (Escribanía 18), cuad. 4, f. 29r, 1473-07-20. 
que deseaba la ampliación de esta última, al menos durante tres años, por 4.501 mrs. anuales solo por la casa, ya que el corral se abonaba por separado por $700 \mathrm{mrs}$. anuales, precio muy elevado, aunque no se indica, como siempre sucede, el tamaño y condiciones de la casa. Se aprecian los precios tan elevados que tenían los alquileres de viviendas en dicha zona ${ }^{74}$.

Esta circunstancia se refleja en la fragmentación en partes que se hizo en diversas casas como se ha podido comprobar en la calle de la Feria, uno de estos lugares tan demandados. Un ejemplo lo tenemos en la toma de posesión de la tercia parte de unas casas en la citada calle entre los cuchilleros por parte del vainero Benito Ruiz, vecino de la misma collación -a los vaineros les interesó residir junto a los cuchilleros, porque a través de ellos obtenían demanda de su trabajo-, por virtud del arrendamiento que le hizo el cuchillero Gonzalo García ${ }^{75}$. El mismo vainero, Benito Ruiz, dos días después, toma la posesión de la mitad de unas casas en la misma calle entre los cuchilleros, por la herencia de su padre, también vainero, Pedro Ruiz, ya fallecido ${ }^{76}$. Y no es este vainero solamente el que tiene casas alquiladas en dicha calle y entre los cuchilleros, pues otro, de nombre Ruy Fernández, alquiló de Diego de Córdoba unas casas-tienda en dicho lugar, de por vida y de la vida de un hijo suyo, por $750 \mathrm{mrs}$. anuales -en este caso el alquiler no fue muy elevado, quizás debido a que fue de por vida, ya que la referencia se toma del testamento de dicho vainero que lo hace estando enfermo y tanto es así que dos días después, ya fallecido, se hace inventario- ${ }^{77}$.

74. AHPCO, PN 13667P (Escribanía 18), f. 490r, 1489-11-16. El total del alquiler por tres años, indicado en dicho contrato es, pues, de $14.203 \mathrm{mrs}$. y parece estar indicando que se pudo abonar por adelantado. Además se señala que el astero en cuestión debía reparar y adobar las casas durante el tiempo que duraba el alquiler. Si el alquiler total se pagó por adelantado, desde luego le urgía la ampliación, quizás por la entidad de su oficio y negocio, y precisaba de más espacio para el almacenaje de las compras que realizaba, pues tenía, entre otras, una relación comercial con un mercader vizcaíno al que le compró hierro, herraje y clavos por valor de $263.000 \mathrm{mrs}$.

75. AHPCO, PN 13666P (Escribanía 18), f. 259r, 1483-08-19.

76. AHPCO, PN 13666P (Escribanía 18), f. 260v, 1483-08-21. Según las lindes debieron formar parte de la misma vivienda del anterior alquiler de la tercia parte, interesándole la ampliación de la ya recibida por herencia.

77. El testamento es AHPCO, PN 13666P (Escribanía 18), ff. 417r-v, 1486-04-18, y el inventario, AHPCO, PN 13666P (Escribanía 18), ff. 418r-419r, 1486-04-20. Las relaciones, tanto con los de su mismo oficio como con los cuchilleros, son evidentes, pues el cuchillero Bartolomé de Segura, hijo de Bartolomé Sánchez, actúa de testigo, tanto en el testamento como en el inventario, donde se mencionan una serie de débitos que tenían contraídos con dicho vainero, el cuchillero Miguel Ramírez, vecino de Andújar -relaciones y solidaridades con otros cuchilleros de fuera de Córdoba-y el vainero Andrés González. Además este testador nombra albaceas a dos personas del oficio, los vaineros Pedro Fernández y Juan Rodríguez, que también fue testigo. Dona toda la herramienta y tablero y todo lo relativo al oficio a su criado Lorenzo, por cargos que de él tiene de buenos servicios. Así pues le debió enseñar dicho oficio y lo tuvo trabajando con él, dado el hecho de esta donación. Entre los bienes inventariados, en los que solo hay bienes muebles, están los relacionados con su trabajo: 124 vainas de puñales dobladas negras y coloradas, 370 vainas de trabajo chicas y grandes, una armera de vainas y de puñales, 80 vainas ganiveteras por acabar, 43 vainas comenzadas a hacer, 12 escribanías por acabar, dos lanceteros de herrador por acabar, una tabla de un torno, una banqueta en una camareta en la que hay ijadas de cueros, un taladro, una tabla pequeña, nueve puñales de trabajo nuevos, cinco puñales escotados barnizados -en referencia al tipo de cabo que llevaba el puñal, que podía hacerse de hierro o de cuero, hecho éste que podía ser participado por ambos profesionales, cuchillero y vainero-, tres 
En la misma calle de la Feria, zona de la collación de San Pedro, había tiendas y casas-tienda, donde aparte de residir tenían su centro de trabajo los cuchilleros, como se indicó anteriormente. Unos las tenían en propiedad y otros en alquiler. Uno de los cuchilleros que compró por 14.000 mrs. una casa-tienda, con tres puertas, fue Gil Álvarez, un caso en que se encuentra la citada frase entre los cuchilleros en el documento de compra ${ }^{78}$. El vendedor fue Francisco de Pineda, vecino de la collación de San Lorenzo, pagando el comprador la alcábala correspondiente. Se comprueba cómo, el citado Francisco de Pineda, el día anterior había comprado dos casas-tienda en la misma calle de la Feria entre los cuchilleros, por 11.000 mrs. ambas y libres de alcábalas, al jurado y escribano público que había sido de Córdoba, Alfonso González, vecino de la collación de Santo Domingo, que las había heredado de su hijo Juan de Córdoba, y las poseía con el arrendamiento de por vida que tenía Gil Álvarez - el cuchillero comprador anterior-y la viuda del vainero Juan López ${ }^{79}$. Es decir, al día siguiente, Francisco de Pineda vende una de ellas al cuchillero Gil Álvarez, que la tenía en alquiler de por vida y estaba interesado en adquirirla en propiedad, lo que evidencia que este negocio le salió muy rentable al vendedor, pues había comprado las dos casas-tienda por $11.000 \mathrm{mrs}$. y vendido una de ellas por 14.000, ganando en un solo día 3.000 mrs. y una casa-tienda. Aquí se observa la rentabilidad y demanda de casas-tienda en aquellas calles y zonas muy comerciales y artesanales, y la habilidad de algunos individuos para los negocios inmobiliarios. Esto es lo que llamaríamos hoy especulación inmobiliaria y que no solo se realiza en las ventas, sino también en los alquileres, especialmente en los subarriendos de casas-tienda y tiendas en las zonas más comerciales.

Uno de los cuchilleros que llegó a tener en propiedad bienes inmuebles, Alfonso Rodríguez, vecino de la collación de San Pedro, poseía unas casas con dos tiendas, con las cámaras y soberados en la calle de la Feria, de la misma collación, que por un importe de 33.000 mrs. las vende al pichelero Juan Martínez, vecino también de dicha collación ${ }^{80}$. Precio importante que muestra que esta zona fue de las más caras de la Córdoba del siglo XV.

puñales escotados nuevos barnizados, 13 cañivetes (cuchillo pequeño) de mesa, nueve cañivetes de calcecabo (llevarían un calce entre el cabo y la hoja para hacer más grueso el mango, como se recoge en las ordenanzas de cuchilleros de 1519), ocho cañivetes de cabo de hierro, etc., además contaba con elementos armeros como "una espada con una guarnición prieta con sus correas" y un capacete viejo (parte de la armadura que cubría la cabeza). Para el transporte contaba con un macho pardillo ensillado y enfrenado, y tenía "una silla vieja de mula con pretal y falsas riendas"; prendas domésticas y de vestir como elementos de sombrerería: bonete y caperuza; calzado detallado como unos borceguíes de badana traídos (de fuera de Córdoba), otros borceguíes de badana viejos, unos zapatos de cordobán amarillos, dos pares de borceguíes de badana viejos; elementos domésticos de cocina y mesa como un plato, un salero y una taza, todos de peltre, etc.; arcas, arquibancos, candiles con sus candeleros y un cascabel de plata. Lo más interesante de todo son los elementos relativos a su trabajo de vainero que estaba interrelacionado con el de los cuchilleros, cuando no ejercía ambos a la vez.

78. AHPCO, PN 13665P (Escribanía 18), cuad. 4, f. 23r, 1473-09-16. La casa lindaba con el adarve y con casa-tienda del vendedor, que tenía alquilada de por vida a Juana López, viuda del vainero Juan López.

79. AHPCO, PN 13665P (Escribanía 18), cuad. 4, f. 58v, 1473-09-15.

80. AHPCO, PN 13668P (Escribanía 18), f. 899r, 1490-08-04. 
En las ocasiones en las que los cuchilleros no son propietarios y las tienen en régimen de alquiler, también hay que tener en cuenta los subarriendos que podían hacer. Así lo reflejan ciertos contratos entre ellos mismos como el que informa que el cuchillero Antón Rodríguez, hijo del vainero Juan Sánchez -una conexión más entre ambos oficios, en este caso dentro de la misma familia-, poseía en régimen de alquiler de por vida una casa-tienda con dos portadas a la calle de la Feria en la collación de San Pedro, cuyo propietario era Pedro de Baena y se la subarrendaba al también cuchillero Juan de Córdoba, hijo de Juan Rodríguez, vecino de la misma collación, durante cinco años. Se acuerda el pago de la renta de forma que el primer año sean $2.700 \mathrm{mrs}$. y un almacén que ha de sacar de otras casas que tiene también alquiladas de por vida, y los otros cuatro años, $3.100 \mathrm{mrs}$. cada uno, además de reparar y adobar dicha casa-tienda durante este tiempo ${ }^{81}$. Se obtienen mejoras y obras en dichas casas-tienda sin coste para el primer arrendador y una cuantía económica elevando la renta. En una zona tan comercial como era la calle de la Feria, con fuertes demandas inmobiliarias, estos subarriendos fueron muy rentables y solicitados, por lo que hubo individuos que se dedicaron preferentemente a este tipo de negocio de los alquileres y subalquileres más allá de su propia actividad artesanal. Igualmente en la plaza de San Salvador, en la collación de San Andrés, los subalquileres de tiendas o casas-tienda, incluso duplicaban la renta anual.

Además se observa en el mismo documento las relaciones entabladas entre los propios cuchilleros, ya que el contrato de subarriendo se hace entre dos de ellos, es lo que se llama corporativismo que pudo abarcar otros campos de la solidaridad profesional o económica con la formación de compañías, fiadurías, etc.

Hay que decir que muchas de las propiedades inmobiliarias de la calle de la Feria estaban en manos de la oligarquía urbana, instituciones religiosas y algunos artesanos y comerciantes de mayor nivel económico. Entre estos propietarios se encuentran Fernando de los Ríos, señor de Fernán Núñez, clérigos de la Universidad, el jurado Gómez Carrillo, el monasterio de la Merced, Luís González de Luna, Monasterio de Santa Clara, etc. En esta misma calle y entre los cuchilleros se encontraba el hospital que dicen del Cuerpo de $\operatorname{Dios}^{82}$.

Las casas-tienda no solo las compraron los artesanos para ejercer la profesión, sino también para alquilar, como hizo el armero Alfonso Rodríguez, que tenía una alquilada en la plaza de San Salvador, entre los aljabibes, al aljabibe Alfonso de Ferrera, durante un año. El documento se hizo por requerimiento de éste al armero ya que hacía dos días que no entraba en dicha casa-tienda porque una viga se estaba cayendo, y exigía su arreglo so pena de dejar dicha casa y no ser obligado a pagar la renta concertada, a lo que el armero contestó que haría lo que con derecho debiere ${ }^{83}$. Se constata que el alquiler era elevado en esta

81. AHPCO, PN 13669P (Escribanía 18), ff. 293r-v, 1493-10-05. Recibió por adelantado 1.860 mrs.

82. AHPCO, PN 14104P (Escribanía 14), ff. 6r-9v, 1461-09-12.

83. AHPCO, PN 13666P (Escribanía 18), f. 305v, 1483-10-13. Los arreglos, mantenimiento y obras nuevas, lo pagaban o hacían los inquilinos, siempre y cuando se concretase en el contrato de 
zona, por un documento de alquiler de la casa-tienda contigua a la del armero mencionado, por el que se pagaban 5.000 mrs. anuales en la misma década de los 80 del siglo $\mathrm{XV}^{84}$.

En otros casos son los armeros los que tuvieron que alquilar casas-tienda para ejercer su oficio en ellas, como Alfonso Sánchez, armero, hijo del también armero Lope Alfonso, vecino de la collación de San Andrés, que la alquiló de Lope de Torreblanca, hijo de Luís Gutiérrez, vecino de San Pedro, estando la misma en la citada collación de San Andrés, junto al pilar del agua de San Pablo, durante tres vidas y una renta anual de $300 \mathrm{mrs}$. y un par de gallinas por navidad, so pena del doble en cada paga no abonada. Esta renta correspondía a 1460, y al ser por tanto tiempo, los alquileres se hacían por menores cuantías, sobre todo por instituciones religiosas, a las que les interesaba alquilar por varias vidas y tener así la conservación del edificio y las rentas aseguradas. En el mismo documento se indicaban las condiciones del alquiler: hacer el tejado que está delante de la casa-tienda durante el primer año, encalar las paredes, y en un plazo de 15 años hacer una cámara en la misma, con suelo de madera, etc., bajo pena de $5.000 \mathrm{mrs}$. en caso de incumplimiento, y cancelar el arrendamiento. El alquiler también se hacía conjuntamente con la esposa del armero, Violante Sánchez, actuando de fiadora su madre, María García, viuda de Juan Rodríguez de Priego, vecina de Santiago, y el tejedor Pedro García de Baena, vecino de San Lorenzo ${ }^{85}$. Así pues, se sigue confirmando que buscaban los lugares más comerciales de la ciudad y de más trasiego de gentes, donde podían ofertar mejor sus artículos e, indudablemente, la collación de San Andrés lo era.

Los adargueros también participaron en dichas inversiones, y podían vivir tanto en casas propias como alquiladas, e igual sucedía con las tiendas o talleres donde trabajaban, tanto en la calle de la Sillería como en la de la Feria. Fueron así mismo partícipes en los subalquileres de otros, dado que si querían estar en el lugar donde se agrupaban los trabajadores de su ramo, y recibir los beneficios derivados de dicha agrupación, no les quedó más remedio que asumir dicha premisa. Por ello el adarguero Miguel Ruiz residía y trabajaba en unas casas-tienda que había subalquilado del sillero de la jineta John Rodríguez por 1.700 mrs. anuales y que éste las había alquilado de los canónigos de San Hipólito ${ }^{86}$. A través de un documento de arrendamiento de una casa-tienda a un correero, conocemos que en la casa-tienda lindante residía y trabajaba otro de los adargueros, de nombre Fernando. Ambas casas-tienda estaban situadas en el Corral de los Correeros de

arrendamiento, aparte del abono de la renta, para que estuviesen terminados al finalizar el tiempo fijado del alquiler y se entregara en buenas condiciones. Aunque en este caso parece entenderse que la viga empezó a caerse con posterioridad a la fecha del contrato y el armero deja ver que actuaría conforme a la ley.

84. AHPCO, PN 13666P (Escribanía 18), f. 787v, 1487-08-31

85. AHPCO, PN 14104P (Escribanía 14), ff. 57v-58v, 1460-07-02. La esposa de dicho armero, dice ser mayor de 14 años y menor de 25 .

86. Así se recoge en el testamento del mencionado sillero de la jineta AHPCO, PN 13665P (Escribanía 18), cuad. 16, ff. 7r-v, 1484-01-08. 
la calle de la Feria, en el tramo correspondiente a la collación de San Nicolás de la Axerquía ${ }^{87}$.

Los profesionales del armamento igualmente invirtieron en bienes rústicos ${ }^{88}$, como el armero Pedro Martínez, hijo del también armero Juan Martínez (familia de armeros citada anteriormente), que tenía viñas en la sierra, en el pago de Valdepuentes $^{89}$-en este pago había además lagares, interesante pues, para utilizarlos por dichos poseedores de viñedos de la zona-. O también armeros como Alfonso Martínez, que arriendan en nombre de otros individuos, en este caso de su yerno Luís Sánchez, al almotacén Diego Fernández, vecino de la collación de San Nicolás de la Villa, un pedazo de viñas, lagar, olivares y árboles con una choza en los puentes del Guadiato, por un tiempo de cuatro años y una renta anual de 2.000 mrs., y en especie, una carga de uvas para colgar y 200 granadas dulces, libres de todos los derechos ${ }^{90}$. Además incluía que hiciera todas las labores necesarias para su mantenimiento.

El yerno confiaba en el armero citado para llevar a cabo satisfactoriamente el alquiler; era una forma de delegar la administración de sus bienes en la persona más idónea, en este caso un miembro familiar.

Otro ejemplo, el del astero Tomás González de Torquemada, que compró un viñedo por 22.500 mrs., situado en el pago de Guadarromán, que debía ser un terreno extenso dado el coste del mismo ${ }^{91}$. $\mathrm{O}$ a una serie de ballesteros que invirtieron en olivares, viñas, lagares, etc ${ }^{92}$.

Pero lo que proporciona mejor información sobre la situación económica de estos profesionales son los testamentos, dotes y, muy especialmente, los inventarios, aunque son escasos los conservados en este período. Un ejemplo de estos últimos es el realizado por la esposa del adarguero ya fallecido Luís de Córdoba, cuyos

87. AHPCO, PN 13665P (Escribanía 18), cuad. 13, ff. 15r-v, 1482-01-02. El documento sirve de ejemplo del arrendamiento de una casa-tienda en la calle de la Feria y en dicho Corral de los Correeros por doña Urraca Méndez, vecina de la collación de Santo Domingo y viuda del señor Fernando de los Ríos, que fue señor de Fernán Núñez, al correero Fernando Alfonso de Mazuela. Dicha casa lindaba con la casa-tienda del adarguero Fernando ya citado. Salió como fiador el cuchillero Lope Ruiz, yerno del correero y vecino de San Pedro. Interrelación vecinal y artesanal evidente, donde se ligaban adargueros, correeros y cuchilleros, incluso familiarmente y con la solidaridad correspondiente.

88. Cabrera Muñoz 1984, pp. 181-197.

89. AHPCO, PN 13665P (Escribanía 18), cuad. 4, f. 54v, 1473-11-01.

90. AHPCO, PN 13666P (Escribanía 18), ff. 85v-87r, 1482-11-04. El alquiler se hacía con una serie de utensilios como tres azadas (una bocancha, otra de pico de ánade y otra puntiaguda), un azadón, dos alforjas de 16 arrobas y una tinaja de seis arrobas.

91. AHPCO, PN 13666P (Escribanía 18), ff. 509v-510r, 1486-08-09.

92. AHPCO, PN 14104P (Escribanía 14), ff. 3v-5v, 1447-02-08. Este documento informa cómo los olivares del ballestero Luís Sánchez, fallecido en esta fecha, estaban en manos de sus herederos, en las cercanías de la Huerta de la Cosida? En AHPCO, PN 13665P (Escribanía 18), cuad. 4, f. 12v, 147311-07, el ballestero Juan Rodríguez poseía unas viñas en el pago de Santa María del Pilar, en la sierra. En AHPCO, PN 13666P (Escribanía 18), ff. 128v-129r, 1483-01-27, el ballestero Luís González, hijo del vainero Diego González, vecino de la collación de San Pedro, poseía una heredad de casas-bodega, lagar, pila y tinajas y cuatro "pedazos" de viña y haza de tierra en el pago del Cortijo de San Cebrián, en la sierra. Todo ello lo alquila a Lope de Rojas y a su esposa Inés Gutiérrez, vecinos de San Lorenzo, durante tres años, por $1.800 \mathrm{mrs}$. anuales y en especie una carga de uvas para colgar, con la obligación de hacer las labores necesarias para el mantenimiento de los bienes alquilados. 
bienes muebles, que en concreto era lo que contenía, fueron valorados en 7.773 mrs. por la ropera Mari Rodríguez ${ }^{93}$. En este inventario se observa la situación propia de un artesano habitual en la época, con unos bienes muebles modestos, pero que se permite unas ciertas licencias o lujos en tejidos y joyas. El mobiliario y ajuar representaban un porcentaje menor en el conjunto de los bienes y pertenencias, tanto en una vivienda pobre como en una casa media, y es precisamente lo que se ve en este inventario como en otros de artesanos cordobeses del mismo tipo. Por supuesto que entre los oficiales de un mismo trabajo o especialidad se pueden observar diferencias a nivel económico-social, derivadas de la demanda, de inversiones en otros campos, de las relaciones comerciales, etc.

Una circunstancia muy importante para valorar la economía de los artesanos del armamento es la dote otorgada por miembros familiares de esta industria a las hijas, o la recibida por ellos al contraer matrimonio. Hay dotes de familias de asteros más elevadas de las que proporcionaban la media de otros profesionales cualificados, del orden de los 60.000 mrs., en las cuales había una aportación monetaria de la mitad de la misma. No era frecuente entre los pecheros la aportación en metálico y aun menos de tal cuantía, salvo que la situación laboral y económica se lo permitiera ${ }^{94}$. Lo que hacía de la futura esposa más deseable para aquél que se casaba con ella, ya que aportaba una cantidad en metálico muy útil para invertir en

93. AHPCO, PN 13665P (Escribanía 18), cuad. 29, ff. 17r-19r, 1497. Falta parte del documento, aunque en lo conservado se indican las prendas domésticas textiles, las de vestir -entre las prendas de los modestos artesanos están las hechas de lino, estopa o de lana, pero también en los mejores casos como el de este inventario, las hay de fuera de la tierra como una azaleja de Holanda, los cabos de deshilado de dos varas y cuarta (cinco reales o $160 \mathrm{mrs}$.), un pañezuelo alemanisco de vara y cuarta (100 mrs.)-. Los útiles de cocina y mesa y otros necesarios en la casa, muebles de la vivienda que, en general, suelen ser escasos y de poca variedad como tres sillas de sentar (dos reales de plata), un arca grande (400 mrs.) -elemento imprescindible y normalmente una, donde se contienen todas las pertenencias-, la mesa de torno de vara y media con su banco y cadena (cinco reales de plata) - tanto puede servir para la comida como para el trabajo, con banco corrido para sentarse (en ocasiones, simples tablones corridos)- . También pueden encontrarse utensilios laborales y alguna joya, que en este caso se trata de "una sortija de oro" (seis reales de plata). Es lo que Rodríguez Vázquez llama "la joya del pobre", una forma de ostentación y de orgullo para este grupo de personas artesanas, el tener este tipo de objetos que no son excesivamente importantes, como "una onza de cuentas de ámbar" (100 mrs.) o “unos corales”. La referencia en Rodríguez Vázquez 1995.

94. AHPCO, PN 13666P (Escribanía 18), f. 897r, 1487-09-14. Diego Sánchez, astero, vecino de Santa María, junto con sus hijos Juan de Córdoba y Rodrigo, astero y mercader, "como hombres que compran y venden sin licencia del dicho su padre", dijeron que es tratado casamiento de Beatriz, hija y hermana de ellos, con Luís de Morales, hijo de Alfonso de Morales, vecino de dicha collación, y cuando el desposorio tenga lugar le darán de dote 60.000 mrs., de los que 30.000 serán en dineros y el resto en ajuar, pagados en esta ciudad desde la fecha hasta un año, y los 30.000 en metálico, dos meses antes de celebrarse las bodas. Indudablemente la carta de dote se hace en esta ocasión con evidente adelanto, puesto que los matrimonios no dejan de ser una transacción económica, aun más cuando el dinero ha de darse dos meses antes de la boda. Además, era la familia al completo de asteros y mercaderes, la que avalaba tal aportación dotal, lo que suponía mayor garantía de cobro para el futuro marido de la hija. El tal Luís de Morales, junto con su madre, María Fernández de Morales, viuda de Alfonso de Morales, vecina de la collación de San Bartolomé, un año después de la anterior carta de dote, da a trueque la cuarta parte del mesón del Granillo de Oro y la cuarta parte del trascorral, en la collación de San Nicolás de la Axerquía, junto a la calleja de la Mancebía, al mercader Juan González Cabeza, vecino de esta última collación, por la mitad de una botica en la calleja de la Mancebía, más 5.000 mrs., perteneciendo 
negocios o en el ejercicio de cualquier profesión con vistas a una ampliación de la actividad o simplemente para la conformación de la nueva familia, lo que no deja de evidenciar el papel de la mujer en la sociedad de estos tiempos como aportadora de la dote. Bernard Vincent dice, en Vera,... en varias ocasiones, 22 exactamente, que la valoración de la fortuna del cabeza de familia está hecha con los bienes de su mujer ${ }^{95}$.

Esta dote contrasta con el inventario de la viuda de un adarguero anteriormente expuesto, consecuencia, posiblemente, de la mejor situación económica y valoración social de los asteros en el conjunto de la ciudadanía cordobesa, que pudo llevarles incluso a alcanzar la caballería de premia, aunque la documentación analizada no lo ha explicitado, pero sí ha expuesto ampliamente sus relaciones comerciales.

En una época donde las guerras y violencias, incluso cotidianas, estaban en el día a día de las ciudades castellanas, se desarrollaba activamente la industria del armamento y sus trabajadores, especialmente los maestros, vivieron en una laboriosidad continua y rentable, tanto en la elaboración de lo nuevo como de aquello que necesitó reparación. Por ello se agruparon en un entorno muy comercial, San Nicolás de la Axerquía y San Pedro, en relación con profesionales afines de las ramas del metal y del cuero, con participación en el negocio inmobiliario de diversas formas o sufriéndolo en el caso de los subalquileres y los sobrecostes de los mismos y de las compras analizadas. Participaron igualmente en la tenencia de viñedos y lagares, un negocio monopolista el del vino, que podía suministrarles una rentabilidad adicional. Se implicaron en las compañías comerciales, pues hubo un fluir muy activo del metal del país vasco hacia la ciudad cordobesa a través, en bastantes ocasiones, de Sevilla, que les resultó sumamente interesante participar en él, especialmente los asteros.

También se observa que el ámbito del préstamo estuvo presente, ya que constituyó otro negocio lucrativo, en un período tan necesitado de él, pues no siempre los pagos a los artesanos y comerciantes se hacían a sus tiempos, y la falta de monetario hacía necesario recurrir a dichos préstamos. O simplemente por necesidad del momento, por relaciones familiares, laborales o de otro tipo que se les podían presentar. El ejemplo en este sentido lo aporta el armero Juan Martínez, que tiene una hija beata, y a través de esta circunstancia otorga un préstamo a una beata de nombre Sancha Fernández, vecina de la collación de Santa Marina, 2.000 mrs., que debía pagar en el plazo de un año bajo pena del doble, dando ésta, como fianza unas casas en Santa Marina, en la barrera de la plazuela de la Mal Pensada -casas que le habían sido donadas por su tío Diego García de Baena, por el buen servicio y por remuneración de muchas honras y buenas obras que de ella ha recibido ${ }^{96}$. Así se comprueba la mayor estabilidad económica de esta familia de armeros y

la otra mitad a la citada viuda: AHPCO, PN 13667P (Escribanía 18), ff. 58v-62v, 1488-12-22. Así pues, esta familia estaba introducida en el negocio de la prostitución.

95. Vincent 1987, p. 280. Leva Cuevas 2008, pp. 69-90.

96. AHPCO, PN 14104P (Escribanía 14), ff. 16r-v, 1460-03-13 y AHPCO, PN 14104P (Escribanía 14), ff. 16v-17r, 1460-03-13. 
los lazos solidarios que pudieron establecer, aunque también los préstamos fueron un negocio lucrativo para los prestamistas, pese a que estuvieran expuestos al impago, y por ello se aseguraban con fianzas e hipotecas. Existen documentos de individuos que recurrían a que se les permitiera una segunda oportunidad para que las deudas no les ahogasen, reflejados en el Archivo General de Simancas, pues la usura también fue una constante y no es de extrañar acusaciones de esta índole a los prestamistas que el mismo Archivo deja ver, como el emplazamiento que se hacía a un tal Pedro de Palacios, vecino de Medina de Rioseco, por parte del Consejo Real, acusado de prestar dinero en Medina del Campo y Valladolid -lugares de ferias- con logro y usura, y de fraude en contratos ${ }^{97}$.

De cualquier manera, los artesanos del armamento, como otros muchos, cuando compraban mercancías o las vendían, quedando pagos pendientes, realizaban contratos de obligaciones donde detallaban estos pagos y los plazos, y en realidad estos documentos asumían unas formas similares a los que se hacían para los préstamos, ya que si no pagaban en los plazos establecidos, se contabilizaba la deuda con el doble como sanción. Como ejemplo, el del astero Diego Sánchez, que se obligó en cuantía de 40.000 mrs. por el mercader Pedro Rodríguez para comprar mercancía en Sevilla en su nombre y posteriormente el mercader pagaría al astero según los plazos que éste fijara ${ }^{98}$. $\mathrm{O}$ el del también mencionado maestro ballestero Miguel Sánchez del Portillo, que recibió un préstamo de 1.000 mrs. por parte de Pedro de Bilbao, afinador de la Casa de la Moneda de Sevilla, que realizó el contrato dos años más tarde de haber recibido dicho préstamo ${ }^{99}$.

Así mismo no extraña en la época el caer preso por deudas, ante la imposibilidad de pagar las obligaciones contraídas. Precisamente un pintor con cierta fama como Pedro Romana, estuvo en la cárcel por esta circunstancia, y fue su cuñado, el también pintor Pedro Anzures, el que pagó la deuda de 3.200 mrs. a los recaudadores Juan de Valladolid y Francisco Jiménez de Plasencia, para que saliera de la cárcel, en $1528^{100}$. Los artesanos del metal y específicamente del armamento, también fiaron a presos por deudas, comprometiéndose al pago de las mismas o a entregarlos en la cárcel del concejo, en un plazo determinado si no hacían posible el pago ${ }^{101}$.

También podemos incluir la confianza mutua entre comprador y vendedor de bienes inmuebles. En este caso, de un pedazo de viñas valorado en 22.500 mrs., visto anteriormente, donde los vendedores recibieron una parte $(10.000 \mathrm{mrs}$.) y el resto sería abonado en diferentes pagos. La confianza del vendedor sobre los com-

97. AGS, RGS, f. 35, 1499-09-30. Valladolid.

98. AHPCO, PN 14104P (Escribanía 14), f. 108v, 1460-12-s. d.

99. AHPCO, PN 13665P (Escribanía 18), cuad. 12, f. 7r, 1480-01-30.

100. Leva Cuevas 2005, p. 23, nota 7.

101. El astero Antón Rodríguez, vecino de la collación de San Nicolás de la Axerquía, fía a Juan Sánchez de la Lancha, vecino de la aldea de Santa María de Trassierra, al que tenía preso el alguacil de la misma, Benito de Buen Rostro, por la deuda de 13.000 mrs. que tenía contraída con Mari González de Mesa, hija del alcaide de Espejo, que debía entregar en la cárcel del concejo de esta ciudad en un plazo de 20 días o pagar dicha cuantía. AHPCO, PN 13665P (Escribanía 18), ff. 595v-596r, 1487-01-15. 
pradores se basaba en que éstos se comprometían a cumplir el pago en los plazos acordados y el vendedor les entregaría la carta de venta una vez finalizados los mismos. En este tipo de contratos siempre va unida una cláusula de penalización en caso de incumplimiento de las partes, como era la pérdida de la cantidad abonada previamente por el comprador o devolución de la cantidad pagada más su doble al comprador si no se le entregaba la carta de venta ${ }^{102}$. Siempre sería preferible no llegar a esos extremos y tener que recurrir a la vía judicial, buscando realizar los contratos con las personas adecuadas, con las que se tuviera la seguridad del pago.

Estos artesanos fueron fiadores en distintas operaciones económicas y mercantiles: alquileres de casas-tienda -como el cuchillero Lope Ruiz, vecino de la collación de San Pedro, lo fue de su suegro Fernando Alfonso de Mazuela, correero, vecino de San Nicolás de la Axerquía, en el alquiler de una casa-tienda en la calle de la Feria, en el Corral de los Correeros ${ }^{103}$; obligaciones -el cuchillero Alfonso Díaz, hijo del también cuchillero Juan Martínez, vecino de la collación de San Pedro, fiador en la obligación contraída por un tal Toledo, escudero del asistente de esta ciudad, con el trapero Pedro González, vecino de Santa María, de cierto paño por un importe de 840 mrs., que debía ser pagado en esta ciudad o en la Feria de Medina del Campo de octubre próximo ${ }^{104}-$, etc. Los fiadores estaban obligados a pagar en caso de que el deudor no lo hiciera, sin perjuicio de que después pudiera cobrarse dicha deuda, por ello, al presentarse como tales, tenían que actuar responsablemente y con cierta garantía de que no iban a salir perjudicados o conocer bien al fiado por tratarse de familiares o compañeros en el oficio y además ser conscientes de que esa era la única solidaridad social posible, ya que las instituciones públicas no practicaban funciones asistenciales ni eran partícipes de garantías de ninguna clase para la población. Pese a todo, se dieron con frecuencia casos de impago ${ }^{105}$. Así

los lazos familiares, vecinales y profesionales, jugaron un destacado papel en la organización del mundo laboral, en la estructura del trabajo, en la composición y evolución de los propios oficios y corporaciones ${ }^{106}$

y, por supuesto, en la vida cotidiana de las gentes.

102. AHPCO, PN 13666P (Escribanía 18), ff. 509v-510r, 1486-08-09.

103. AHPCO, PN 13665P (Escribanía 18), cuad. 13, ff. 15r-v, 1482-01-02.

104. AHPCO, PN 13665P (Escribanía 18), cuad. 28, f. 8r, 1461-07-04.

105. AHPCO, PN 13665P (Escribanía 18), cuad. 34, f. 32r, 1502-04-12. El cuchillero Diego de Madrid, hijo de Fernando Serrano, vecino de San Pedro, recibió un pago de Antón de Castillejo, vecino de Obejo, de 20 reales y medio de plata castellanos (697 mrs.), ya que salió fiador por Benito Muñoz de la Cuerda, vecino de Córdoba, pasándole el poder y la documentación pertinente para que pudiera cobrar.

106. Córdoba de la Llave 2017, p. 226. 


\section{LAS RELACIONES SOCIALES Y LAS CONFIANZAS MUTUAS}

Los profesionales tratados, tuvieron una buena aceptación social, una confianza en su buen hacer en las delegaciones que recibieron como las acciones testificales, nombramiento de albaceas testamentarios, de tutores y curadores, hermanos de cofradías, etc. Los armeros Alonso Pérez, hijo de Alonso Pérez, y Juan Alonso, hijo de Juan Alonso, sirvieron de testigos en el alquiler de las casas-mesón que se dicen de la Catalana (mesón del Potro), cuyo propietario era la Iglesia Mayor ${ }^{107}$. También los espaderos Juan Garrido y Benito Fernández, vecinos de San Nicolás de la Axerquía, fueron testigos en el testamento de Leonor Fernández, esposa del dorador Juan Pérez, vecina de la misma collación ${ }^{108}$.

En ocasiones actuaron a la vez como testigos y albaceas como el adarguero Miguel Ruiz, que lo fue de Inés Fernández Merina, esposa del platero Juan Daza, vecina de la collación de Santa María ${ }^{109}$. Otro ejemplo fue el del adarguero Alfonso Martínez, que fue albaceas y testigo en el testamento de su compadre John Rodríguez, sillero, por la gran relación que existía entre ellos ${ }^{110}$. El mismo adarguero, fue igualmente compadre de otro sillero, Francisco Martínez, vecino de San Nicolás de la Axerquía, que lo nombró albaceas en su testamento ${ }^{111}$. La relación del adarguero con los silleros es más que evidente, pero no solo con ellos, pues vuelve a actuar como albaceas, junto con el correero Ruy García, en el testamento de María Rodríguez, esposa del herrador Juan Rodríguez, vecina de San Nicolás de la Axerquía ${ }^{112}$. Pero Alfonso Martínez estuvo más implicado en la vida cordobesa por ser hermano de la cofradía del Hospital de la Santa Caridad de Jesucristo,

107. AHPCO, PN 13669P (Escribanía 18), ff. 603v-604r, 1494-03-11. Así mismo fueron testigos: el armero Juan Rodríguez, hijo del también armero Diego Alonso, en el documento AHPCO, PN 13665P (Escribanía 18), cuad. 4, f. 29r, 1473-07-23; el armero Fernando, hijo del también armero Antón Ruiz, en AHPCO, PN 13665P (Escribanía 18), cuad. 27, s. f., 1495-05-12; Antón Rodríguez, armero, hijo de Fernando Rodríguez, en un arrendamiento de lagar, en AHPCO, PN 14104P (Escribanía 14), ff. 3v-4r, 1460-02-10; Alfonso Rodríguez, armero, hijo del también armero Alfonso Rodríguez, en la modificación de un testamento, en AHPCO, PN 13665P (Escribanía 18), cuad. 10, f. 6v, 1478-0221; ambos, padre e hijo, actuaron de testigos en el testamento del sastre Enrique Alemán -su apellido delata su origen-, vecino de la collación de San Pedro, en AHPCO, PN 14104P (Escribanía 14), ff. 9v11r, 1464-06-02; este mismo hijo lo fue también en el testamento de la esposa del citado sastre, Mencía Díaz, en AHPCO, PN 14104P (Escribanía 14), ff. 4r-5v, 1464-05-29; Luís, armero, hijo del también armero Sebastián Ruiz, en el alquiler de unas piedras de aceña en la parada de aceñas de don Tello, en el Guadalquivir, propiedad compartida por la Iglesia Mayor, el señor de Fernán Núñez y otros señores de la oligarquía urbana, en AHPCO, PN 14104P (Escribanía 14), ff. 27r-28v, 1464-06-25. Igualmente se encuentran más armeros ejerciendo como testigos en los documentos AHPCO, PN 14104P (Escribanía 14), f. 18v, 1461-10-04; AHPCO, PN 13665P (Escribanía 18), cuad. 4, ff. 8r-v, 1474-10-02; AHPCO, PN 13665P (Escribanía 18), cuad. 9, ff. 4r-v, 1477-05-31 y AHPCO, PN 13665P (Escribanía 18), cuad. 12, f. 7v, 1480-01-31.

108. AHPCO, PN 13669P (Escribanía 18), ff. 525r-526r, 1494-02-13.

109. AHPCO, PN 13665P (Escribanía 18), cuad. 30, ff. 44r-45v, 1488-05-15.

110. AHPCO, PN 13665P (Escribanía 18), cuad. 16, ff. 7r-v, 1484-01-08. Este adarguero era hijo del también adarguero del mismo nombre, Alfonso Martínez.

111. AHPCO, PN 13667P (Escribanía 18), ff. 162r-v, 1489-04-06.

112. AHPCO, PN 13667P (Escribanía 18), ff. 557r-558r, 1490-01-15. En este caso, el adarguero era primo de la testadora. 
una cofradía importante, a la que llegaban bastantes donaciones de la ciudadanía a través de los testamentos principalmente ${ }^{113}$.

El armero Juan Martínez, tío del testador Garci Ferrández, espartero, vecino de la collación de San Pedro, fue nombrado albaceas por éste, y recibió poder para cumplir todo lo dicho en el testamento, lo que supone un vínculo familiar de confianza y solidaridad ${ }^{114}$. Los asteros debieron alcanzar una muy buena valoración social y económica, ya que estuvieron presentes en testamentos de otras personas que confiaron en ellos como para designarlos albaceas y tutores, como el astero Tomás González de Torquemada, vecino de San Nicolás de la Axerquía, que fue nombrado albaceas por Juana García en su testamento, y como tal tenía que encargarse de cumplir lo expuesto por la testadora. En este caso entregó al yerno de la misma, Pedro Callado, morador en Córdoba, un florín de oro y seis reales de plata, que la dicha Juana García había recibido en guarda ${ }^{115}$.

Indudablemente su actuación como tutores y curadores vino derivada de su reputación o por el conocimiento que tuvieron de ellos, que iba a influir en dicha designación, que se efectuaba a través de los testamentos y que también se ponen de manifiesto en los finiquitos, que a tales tutores otorgaban los tutelados, informando de la buena cuenta de las herencias, cuando éstos ya llegaban a la mayoría de edad. Se dieron casos de mal uso de las herencias de tales menores que llegados a su mayoría se vieron obligados a reclamar judicialmente. Estos tutores y curadores no solo tenían que mantener las herencias, sino que debían hacer buenas inversiones de ellas a fin de ampliarlas, lo que no siempre fue fácil en unos tiempos en que la menor circunstancia adversa podía ocasionar una caída económica de la inversión realizada. Un ejemplo de buena administración es la realizada por el cuchillero Pedro Ruiz, hijo de Pascual Sánchez, vecino de la collación de San Lorenzo, que dio buena cuenta de todos los bienes raíces y muebles, que a Andrés García de Córdoba, hijo de Antón Ruiz de Lora, vecino de la Magdalena, le pertenecieron heredar de sus padres y también después del finamiento de sus hermanos Marcos y Nicolás. Andrés García le otorgó finiquito ${ }^{116}$.

En todos los aspectos se concluye que hay una solidaridad familiar de carácter económico, a través de las fiadurías y el pago de deudas entre los diversos familiares, incluidos suegros, cuñados, etc., como también en las tutorías para velar por los intereses de los menores de las familias cuando el padre faltaba. En esta solidaridad se puede incluir la transmisión del oficio de padres a hijos y así sucesivamente. En algunos casos como el de los escribanos públicos ${ }^{117}$, se observa una especie de constitución de linajes del oficio, pero en la mayoría de las profesiones no es tan fácil evidenciarlo, no obstante sí que en todas se encuentra una cier-

113. AHPCO, PN 13667P (Escribanía 18), ff. 263r-v, 1489-06-24. El citado adarguero, junto con el hermano mayor Juan Sánchez, espartero, y los también hermanos Antón García y Pedro Díaz, correero, compran para dicho hospital unas casas en la collación de Santa Marina, a Bartolomé Rodríguez Guerrero, alforjero y espartero, vecino de la collación de San Pedro, por $8.000 \mathrm{mrs}$.

114. AHPCO, PN 14104P (Escribanía 14), ff. 59v-61v, 1460-07-07.

115. AHPCO, PN 13666P (Escribanía 18), f. 337r, 1483-11-18.

116. AHPCO, PN 13666P (Escribanía 18), ff. 719r-v, 1487-05-30.

117. Leva Cuevas 2009, pp. 63-93. 
ta continuidad como en los oficios del armamento se ha constatado. Así mismo también se ha evidenciado una interrelación entre los oficios más afines o complementarios. Se dio una solidaridad profesional visible a través de la formación de compañías laborales y mercantiles, más allá de los propios negocios y aquí se incluirían igualmente las fiadurías entre miembros de la profesión u oficios afines. Se ha observado la actuación de artesanos como intermediarios en la venta de las materias primas necesarias al oficio, como los asteros con la compra y venta del metal obtenido de mercaderes vascos, no solo para su propia actividad, sino como negocio subsidiario en las ventas a otros artesanos. Participantes en el cobro de deudas por delegación de otros profesionales, como en la recepción u otorgamiento de préstamos o las procuraciones entre ellos, de carácter económico, en pleitos, etc.

Otras solidaridades son las gremiales y religiosas o aportadas por las cofradías, incluso la creación de hospitales por éstas. En realidad no dejaban de suponer, en muchos aspectos, una especie de corporativismo, pues en el siglo XV suelen ir unidas al oficio. Puñal Fernández, llega a señalar que la presencia de artesanos en las cofradías podía enmascarar cofradías de oficio convertidas en hermandades de tipo benéfico-asistencial, dado que la legislación castellana, desde el siglo XIII, prohibía la formación de ligas y monipodios, versus cofradías, si no era con fines benéficos o religiosos ${ }^{118}$.

\section{CONCLUSIONES}

La idiosincrasia de la sociedad bajomedieval, belicista y conflictiva, basada en los principios de jerarquía y desigualdad, donde la nobleza imponía sus ansias de poder y de dominio, la dividió en distintos frentes, llegando incluso a las guerras civiles, unida también a los siglos de guerra contra los musulmanes, la llevó hacia una fuerte mentalidad guerrera.

Por otra parte estaba la milicia ciudadana, que iba con los reyes a combatir en guerras y conflictos, compuesta por caballeros y los peones $u$ hombres a pie, donde se incluían pequeños burgueses y pecheros, artesanos y campesinos, que conformaban los cuerpos de lanceros, ballesteros y espingarderos. Los caballeros se entrenaban en las palestras, en la caza mayor y en los torneos ${ }^{119}$.

Existía igualmente una violencia cotidiana en esta sociedad, y para su estudio son muy importantes las cartas de perdón, que se encuentran en los Protocolos Notariales de esta ciudad, consecuencia de la violencia, presente entre la población cordobesa en este caso, e igual en toda la península. Por una cuantía monetaria podían ser perdonados los agresores, incluso en casos de muerte. Esta violencia abarcaba a todas las capas sociales y artesanales. Bajo fórmulas hipócritas de que se perdonaba por bien de paz y de concordia o por amor a Jesucristo o

118. Puñal Fernández 2000, p. 144

119. Las justas y torneos eran violencia ritualizada, donde los contendientes podían morir o ser heridos gravemente o mutilados. Pero recibían la sanción del estado y de la iglesia, caos controlado. Ruiz 2002, pp. 179-180. 
por reverencia a Dios, etc., y después todo se resolvía como un negocio más. Desigual justicia, no solo entre los privilegiados y clases bajas, sino entre el mismo pueblo, pues aquellos que podían pagar tenían la posibilidad de ser perdonados y no recibir castigo. Incluso la violencia y la marginación llevaron a emigrar a otros lugares a causa de persecuciones judiciales y posibles venganzas a individuos que participaron en actos violentos, y algunos con tan buena suerte como aquellos que conformaron familias de mercaderes muy importantes, caso de Burgos a finales del siglo $\mathrm{XV}^{120}$.

Otras violencias a tener en cuenta: sexual, paternal, contra las mujeres ${ }^{121}$, la prostitución organizada, movimientos de resistencia, la picaresca, juegos, etc., sin olvidar la Inquisición. Sociedad, pues, violenta ${ }^{122}$.

Los artesanos del armamento cobraron un papel destacado en este tipo de sociedad y constituyeron un cuerpo muy cualificado, especialmente armeros y espaderos, pero también hubo asteros que, además tuvieron un papel muy interesante en el comercio del hierro con mercaderes vascos $-\mathrm{y}$ es, quizás, donde mejor se observa esa interrelación del artesano comerciante entre estos profesionales del armamento-, y vinieron a Córdoba asteros de dicho origen a trabajar en nuestra ciudad. Continúa la nómina de especialistas con ballesteros, cuchilleros, malleros, vaineros y adargueros -los dos últimos, pertenecientes a la rama del cuero-.

Los armeros fabricaban las piezas de protección del guerrero, armaduras, corazas, coseletes, etc., así como las armas que utilizaban los caballeros. Fabricaron espadas como los espaderos, el arma noble por excelencia ${ }^{123}$, por ello gozaron de prestigio. Las ordenanzas de 1512 exponían que era un oficio de calidad e importante para defender y proteger la vida de los hombres, por cuanto se debía evitar corruptelas, falsificaciones, fraudes e interferencias de otros profesionales de diferentes actividades, como caldereros, herreros, etc.

Las armas estuvieron muy presentes en la sociedad del momento, incluso en contratos de aprendizaje de otros oficios como el de bonetero, donde se incluían, entre lo que debía dar el maestro al aprendiz, armas, como una ballesta de acero con todo su aparejo ${ }^{124}$. En los inventarios y otros tipos de documentos, se reflejaba

120. Caunedo del Potro 2011, pp. 123-133.

121. Leva Cuevas 2008, PP. 69-90.

122. Curioso ver la cantidad de contratos que se hacen para sustituir al titular de prestar servicio militar por otra persona a la que se contrataba por una mayor o menor cantidad monetaria, según la categoría militar del titular. En una sociedad tan mentalizada en la violencia, no obstante, imperaba la responsabilidad de no dejar desprotegida a la familia si faltaba la actividad laboral de éste durante el período que duraba dicha prestación, ya que se trataba también de una sociedad desprotegida asistencialmente. Aunque aquí también jugaba la necesidad del contratado y la posibilidad del contratador de pagar para evitar ir a la guerra.

123. La nobleza y oligarquía urbana llegó a tener sus propios espaderos, como Andrés de Hoces, vecino de la collación de San Andrés, que tenía como su espadero a Diego Alfonso de Clavijo, al cual le daba poder especial para recaudar y dar cartas de pago de lo que le fuere debido, y general en sus pleitos y negocios - confianza plena en tal persona-. AHPCO, PN, 13665P (Escribanía 18), cuad. 6, f. $49 \mathrm{v}, 1474-07-18$.

124. AHPCO, PN, 13666P (Escribanía 18), f. 114v, 1483-01-08. 
la posesión de armas: lanzas, espadas, ballestas, etc. ${ }^{125}$ y así se encuentran casos como el del mayordomo de los señores deán y cabildo de la catedral de esta ciudad, Pedro González, vecino de la collación de Santa María, en cuyo inventario de bienes figuraban un par de corazas, dos espadas, un broquel ${ }^{126}$.

Dos collaciones tuvieron la primacía en la residencia y lugar de trabajo de los artesanos del armamento, las de San Nicolás de la Axerquía, preferida por armeros, espaderos, asteros y adargueros, y San Pedro, elegida por ballesteros, cuchilleros y vaineros. En ambas collaciones, todos estos trabajadores se concentraron entre la calle de la Feria y la calle y plaza del Potro, como se ha podido observar a través de los Protocolos Notariales y del Padrón de 1509.

En cuanto a la evolución temporal de estos profesionales en el período analizado, se observan pocas variaciones en el número, cualidades y valoración socioeconómica de cada uno de los oficios.

\section{BIBLIOGRAFÍA}

Bernal Estévez, Ángel (1988), "Las armas como concepto fiscal y de diferenciación social en la Baja Edad Media", Gladius. Etudes sur les armes anciennes, l'armement, l'Art militaire et la vie culturelle en Orient et Occident. Tomo especial, pp. 21-30.

Bruhn de Hoffmeyer, Ada (1988), "Las armas en la historia de la Reconquista", Gladius. Etudes sur les armes anciennes, l'armement, l'Art militaire et la vie culturelle en Orient et Occident. I Simposio Nacional sobre las armas en la Historia (Marzo, 1983). Tomo especial, pp. 31-99.

Cabrera Muñoz, Emilio (1984), "El campesinado y los sistemas de propiedad y tenencia de la tierra en la Campiña de Córdoba durante el siglo XV", Actas del III Coloquio de Historia Medieval Andaluza, Jaén.

Caunedo del Potro, Betsabé (2011), "Entre la violencia y la marginación: el establecimiento en Burgos de futuros mercaderes", Meridies, 9.

Córdoba de la Llave, Ricardo (1984), "Notas para el estudio de los aprendices en Córdoba a finales del siglo XV", Ifigea.

Córdoba de la Llave, Ricardo (1988), “El comercio del hierro en Córdoba, un capítulo de la actividad económica vascongada en Andalucía a fines de la Edad Media", Congreso de Historia de Euskal Herría, Instituciones, economía y sociedad (siglos VIII-XV). Tomo 2. San Sebastián.

Córdoba de la Llave, Ricardo (1990), La industria medieval de Córdoba, Córdoba.

Córdoba de la Llave, Ricardo (1991), "Distribución sectorial de los artesanos cordobeses del siglo XV", Actas del II Congreso de Historia de Andalucía, Córdoba.

125. AHPCO, PN, 13666P (Escribanía 18), f. 685r, 1487-04-06, es un contrato de servicio militar, donde se entrega espada en propiedad, aparte de la cuantía monetaria por el servicio.

126. AHPCO, PN, 13666P (Escribanía 18), ff. 889r-898r, 1488-09-12. 
Córdoba de la Llave, Ricardo (2016), "El acceso de los jóvenes al mundo laboral en las ciudades hispanas a fines de la Edad Media", La formació de la personalitat a l'edat mitjana. XIX Curs d'Estiu Comtat d'Urgell, Lleida.

Córdoba de la Llave, Ricardo (2017), Los oficios medievales, Madrid.

Edwards, John (2001), La España de los Reyes Católicos (1474-1520), Barcelona.

Escobar Camacho, José Manuel (1989), Córdoba en la Baja Edad Media, Córdoba.

Fossier, Robert (2002), El trabajo en la Edad Media, Barcelona.

Franco Silva, Alfonso (1992), Esclavitud en Andalucía. 1450-1550, Granada.

Gestoso Pérez, José (1911), "Esgrimidores sevillanos", Revista de Archivos, Bibliotecas y Museos, Madrid.

González Arce, José Damián (1998), Apariencia y poder. La legislación suntuaria castellana en los siglos XIII-XV, Jaén.

Leva Cuevas, Josefa (2000), "La actividad profesional en Córdoba según el Padrón de 1509", Ámbitos, n³.

Leva Cuevas, Josefa (2004), "La caballería y el Arte de la Esgrima en la ciudad de Córdoba en los siglos XV y XVI. La plaza de la Corredera como marco de su ejercicio", Ámbitos n ${ }^{\circ} 11$.

Leva Cuevas, Josefa (2008), "El papel de la mujer en la Baja Edad Media. La dote, ¿impulsora del nuevo hogar o yugo para las mujeres?”, Ámbitos no 19.

Leva Cuevas, Josefa (2009), "Escribanos y Notarios en la Castilla Bajomedieval. Su ejercicio en la Córdoba de la época", Ámbitos no 21.

Leva Cuevas, Josefa (2010), "Cuestión de términos: un poder muy feudal”, Actas de las III Jornadas sobre Historia de Montemayor, Córdoba.

Lora, Gloria (1982), "Notas sobre el comercio de esclavos en Córdoba a fines del siglo XV", Actas del II Coloquio de Historia Medieval Andaluza, Sevilla.

Martínez Martínez, Julio Gerardo (1988), "La significación del término "Armas", los modismos lingüístico-jurídicos y su valoración en la estética medieval", Gladius. Etudes sur les armes anciennes, l'armement, l'Art militaire et la vie culturelle en Orient et Occident. Tomo especial.

Miura Andrade, José María (1988), "Beatas y beaterios andaluces en la Baja Edad Media. Su vinculación con la Orden de Predicadores", Actas V Coloquio Internacional de Historia Medieval de Andalucía. Andalucía entre Oriente y Occidente.

Miura Andrade, José María (2017), "Formas de vida religiosa femenina en Carmona (siglos XV al XVI). Beaterios y conventos", Actas del X Congreso de Historia de Carmona.

Moxó, Salvador de (1961), "Exenciones tributarias en Castilla a fines de la Edad Media”, Hispania, 21.

Páez García, Mateo (1994), "Notas en torno a aspectos sociales de la esclavitud en Córdoba a comienzos del siglo XVI", Actas del II Congreso de Historia de Andalucía. Historia Medieval II, Córdoba.

Peláez Valle, José María (1988), "La Espada Ropera Española en los siglos XVI y XVII", Gladius. Etudes sur les armes anciennes, l'armement, l'Art militaire et la vie culturelle en Orient et Occident, pp. 147-199. 
Pino García, José Luís; Córdoba de la Llave, Ricardo (1988), "Los servicios sustitutivos en la guerra de Granada: el caso de Córdoba (1460-1492)", Relaciones Exteriores del Reino de Granada, Almería.

Puñal Fernández, Tomás (2000), Los artesanos de Madrid en la Edad Media (1200-1474), Madrid.

Rodríguez Vázquez, Antonio L. (1995), Ricos y pobres. Propiedad y vida privada en la Sevilla del siglo XVI, Sevilla.

Ruiz, Teófilo F. (2002), Historia social de España, 1400-1600, Barcelona.

Vincent, Bernard (1987), Minorías y marginados en la España del siglo XVI, Granada. 